\title{
Minimizing Temperature Fluctuations of Sandy Soil Under Different Climatic Conditions
}

\author{
A. A. El-Kharbotly, E. M. Hokam, A. Y. Genead and \\ S. A. Mohamed. \\ Soils and Water Dep., Faculty of Agriculture, Suez Canal \\ University, Ismailia, Egypt.
}

\begin{abstract}
QANDY soils, in the arid regions, usually suffer from extreme temperatures. Such high temperature fluctuations can be harmful for plant growth. This investigation aimed to: 1) detect soil thermal regime of Ismailia coarse texture soils; 2) study soil temperature fluctuations under different climatic conditions; 3) determine evaporation rate of soil water; 4) study the effect of some soil surface treatments on the $2^{\text {nd }}$ and $3^{\text {rd }}$ points. All the four aims were studied under both summer and winter conditions. The investigated soil surface treatments included transparent plastic mulch, rice straw mulch, application of bentonite, and the control. Obtained results revealed that, the thermal regime of Ismailia sandy soil was Hyperthermic. The response of soil temperature to air temperature fluctuation was more pronounced during winter compared to summer conditions. The highest soil temperature fluctuation was obtained under transparent plastic mulch and the lowest was obtained under rice straw mulch, during both summer and winter seasons. The highest soil temperature values recorded under plastic mulch can be harmful for plants during the summer, but may enhance plant growth during the winter. Both rice straw and plastic mulch reduce the water loss by evaporation from soil surface, as indicated from the evaporation rate. Bentonite incorporation with the soil surface layers had small effects on both soil temperature fluctuation and water evaporation rate. It is recommended to use straw mulch for moderating soil temperature fluctuations and reducing water loss by evaporation during summer and winter seasons.
\end{abstract}

Keywords: Soil temperature fluctuation, Transparent plastic mulch, Straw mulch, Drying front.

Early in 1959, Geiger stated that "calcareous soils are cold ones, wet soils are also cold, and sandy soils suffer from extreme temperature". Soils temperature varies greatly with depth and over time. Temperature in the upper soil layers fluctuates substantially in response to changes in air temperature, irradiation and radiant heat transfer, whereas temperature is more stable in the deeper soil layers. Soil temperature has a substantial influence on root growth. The minimum and optimal temperatures depend upon the plant species and are typically in the ranges of $0-12^{\circ} \mathrm{C}$ and $25-35^{\circ} \mathrm{C}$, respectively, while the maximum is almost around $40-45^{\circ} \mathrm{C}$ (Gregory, 2006).Consequently, it is thought that amelioration of upper layer temperature in sandy soil is beneficial for growing economical plants. 
This could be done by trialing to lower its temperature during the hottest days of summer and/or worming up during the coldest days of winter.

Soil temperature can be managed in numerous ways, which includes mulching, tillage, irrigation, drainage, cover crop or shading, and application of dark or light powder. The management procedures depend on whether the temperature of soil needs to be increased or reduced (Lal and Shukla, 2004). Anikwe et al. (2007) observed that, the average soil temperature under transparent plastic mulch was predominantly higher than that under black plastic mulch by about $1-2{ }^{\circ} \mathrm{C}$. However, the soil temperature under non-mulched condition was lower by $1-3{ }^{\circ} \mathrm{C}$ compared to the soil temperature under mulch. In another study transparent plastic mulch resulted in increasing the mean daily topsoil temperature by about $2.5-3.2^{\circ} \mathrm{C}$ than that under non-mulched soil during the early growing season. However the difference in the topsoil temperature was less pronounced as the plant canopy grew (Zhao et al., 2012). Recently, Yaghi et al. (2013) also indicated that plastic mulch generally raised soil temperature, whereas transparent plastic mulch raised the limits of the soil temperature by 6.4 , 5.9 and $5.6{ }^{\circ} \mathrm{C}$ at soil surface, $5 \mathrm{~cm}$, and $10 \mathrm{~cm}$ soil depth, respectively. While black plastic mulch raised the limits of the soil temperature by $3.1,2.7$ and $2.4{ }^{\circ} \mathrm{C}$ respectively at the same previous soil depth, compared with non-mulched soil. Kirnak et al. (2003) reported that, the plastic mulches has an ability to improve soil moisture, consequently, improves nitrogen availability for plants.

Zhang et al. (2009) used wheat straw in a rate of $0.8 \mathrm{~kg} \mathrm{~m}^{-2}$ as a surface mulch. They observed that, soil temperature under mulch was higher during the colder weather and lower during warmer weather compared with non-mulched soil. Olasantan (1999) and Fabrizzi et al. (2005) found the same trend. Meanwhile, the magnitude of the change in soil temperature due to mulching varies between studies. This variation could be attributed to the mulch application rate and/or climate conditions. In addition to the effect of straw mulch on soil temperature, Dahiya et al. (2007) concluded that, due to the evaporation property of the surface placed straw layer, mulching treatment reduced soil water loss on an average by $0.39 \mathrm{~mm} \mathrm{~d}^{-1}$ compared to non-mulched soil during the study period.

Very few published studies have examined the effects of bentonite application on soil thermal properties and heat flow. In this regard Zvomuya et al. (2008) reported that, application of drilling mud (aqueous suspension of bentonite primarily $\mathrm{Na}$-montmorillonite) provide evidence of significant alteration of the investigated important micrometeorological parameters. Surface albedo decreased by $15 \%$ to $18 \%$. The lower albedo meant that a greater proportion of incoming shortwave solar radiation was available for partitioning into soil heat flux and other components of the surface energy balance equation. This partly explains the observed increases in soil heat flux at $0.05 \mathrm{~m}$ depth with mud application, resulting in corresponding increases in soil temperatures measured in the soil layer above the soil heat flux plates. By modifying heat flow and temperature in the root zone, drilling mud application may alter critical ecosystem biophysical

Egypt. J. Soil Sci. 56, No. 2 (2016) 
and physiological processes, with important implications for overall biological productivity. The direction and magnitude of such changes, in conjunction with all other ecological effects, will ultimately define the sustainability of the practice in this ecosystem (Zvomuya et al., 2008).

\section{Materials and Methods}

The soil used in the current investigation was coarse texture soil collected from the Experimental Farm of the Faculty of Agriculture, Suez Canal University, Ismailia, Egypt. The coordinates for this location are $30^{\circ} 37^{\prime} \mathrm{N}$ and $32^{\circ} 16^{\prime} \mathrm{E}$. The air dried soil samples were subjected to chemical and physical analysis. Some selected chemical properties were determined using the methods described by Sparks (1996), and the investigated physical properties were determined as described by Klute (1986) and presented in Table 1. The soil was a Typic Torripsamments according to the system outlined by Soil Survey Staff (1993).

TABLE 1. Some chemical and physical properties of investigated soil

\begin{tabular}{|c|c|c|c|c|c|c|c|}
\hline \multicolumn{8}{|c|}{ Physical properties } \\
\hline \multicolumn{4}{|c|}{ Particles size distribution } & \multirow{3}{*}{$\begin{array}{c}\text { Texture } \\
\text { Class }\end{array}$} & \multicolumn{2}{|c|}{ Densities } & \multirow{3}{*}{$\begin{array}{c}\begin{array}{c}\text { Total } \\
\text { porosity }\end{array} \\
\%\end{array}$} \\
\hline C. sand & F. sand & Silt & Clay & & Bulk & Particles & \\
\hline \multicolumn{4}{|c|}{$\%$} & & \multicolumn{2}{|c|}{$\mathrm{Mg} \mathrm{m}^{-3}$} & \\
\hline 80.1 & 15.1 & 1.8 & 3.0 & Sand & 1.631 & 2.596 & 37.17 \\
\hline \multicolumn{8}{|c|}{ Chemical properties } \\
\hline \multicolumn{2}{|c|}{$\mathrm{EC}_{\mathrm{e}}^{\dagger}$} & \multirow{2}{*}{\multicolumn{2}{|c|}{$\mathrm{pH}^{\dagger \dagger}$}} & \multicolumn{2}{|c|}{$\mathrm{CaCO}_{3}$} & \multicolumn{2}{|c|}{$\mathrm{OM}$} \\
\hline \multicolumn{2}{|c|}{$\mathrm{dSm}^{-1}$} & & & \multicolumn{4}{|c|}{$\%$} \\
\hline \multicolumn{2}{|c|}{1.5} & \multicolumn{2}{|c|}{7.31} & \multicolumn{2}{|c|}{1.3} & \multicolumn{2}{|c|}{0.14} \\
\hline
\end{tabular}

In soil paste extract

\section{Column preparation}

Total of 18 PVC soil columns were used in the current investigation. These PVC columns were $0.005 \mathrm{~m}$ in wall thickness, $0.19 \mathrm{~m}$ in diameter and $0.45 \mathrm{~m}$ in length. The bottom end for each column was sealed with perforated cap. Just above the bottom end, a layer of pre-washed cheesecloth was placed. Each column was packed with $0.40 \mathrm{~m}$ total soil depth, with the same bulk density, at which the soil was found in the field. Incremental packing of soil samples involved the use of five centimeters soil depths packed in each column. Each soil depth was packed using a "powder funnel" with a plastic extension tube in order to reach deep down in the column. The extension tube was gradually raised to minimize particles segregation as packing proceeded (Bellini et al., 1996). A wooden rod, with a studded surface, was used during the successive packing soil sections, to bring the soil bulk density to the desired value, and to prevent partial particles layering within each soil section. 
During successive packing total of 5 temperature sensors (LM35), for each soil column, were placed horizontally in holes drilled along the side of the columns at depths of $0.01,0.06,0.15,0.25$ and $0.35 \mathrm{~m}$ from the soil surface. To minimize lateral temperature transfer, the columns were insulated from outside with $1 \mathrm{~cm}$ Styrofoam layer covered with aluminum foil sheet.

After these six treatments have been begun, each one included three soil columns. The $1^{\text {st }}$ treatment dealt with covering soil surface by $1.25 \mathrm{~mm}$ thickness transparent polyethylene sheets, TP, where a hole of $1 \mathrm{~cm}$ diameter was made in the center of each TP sheet. The $2^{\text {nd }}$ treatment was use of $10-15 \mathrm{~cm}$ rice straw pieces as surface mulch applied in a rate of $8 \mathrm{Mg} \mathrm{ha}^{-1}$ on soil surface, R8. The $3^{\text {rd }}$ treatment involved the use of $4 \mathrm{Mg} \mathrm{ha}^{-1}$ rice straw as a soil surface mulch, R4. A fishing net was used to stabilize the straw on soil surface. The $4^{\text {th }}$ treatment was the incorporation of $16 \mathrm{Mg} \mathrm{h}^{-1}$ of the bentonite (1 Na:1 Ca - bentonite) mixed with the top $0.1 \mathrm{~m}$ soil layer before packing, B10. Similar to this treatment, the $5^{\text {th }}$ treatment involved the incorporation of $16 \mathrm{Mg} \mathrm{h}^{-1}$ bentonite but mixed with the top $0.2 \mathrm{~m}$ soil layer, B20. The last treatment was the control, C.

\section{Moisture and temperature measurements}

After packing the columns, irrigation water from Ismailia canal was added to bring soil moisture content to its field capacity. Soil columns were subjected to natural evaporation, where the first level of evaporation extended until its moisture content reduced by $15 \%$ from soil field capacity. Such reduction was detected by weighing the soil columns with a digital balance $(30 \mathrm{~kg} \pm 1.0 \mathrm{~g})$ at constant time every day. During the evaporation process each soil segment represented a layer specified for determining soil temperature. Afterwards, the specified soil column was excluded for soil moisture determination. It was dissected into $0.10 \mathrm{~m}$ soil sections (the upper section was divided into top $0.02 \mathrm{~m}$ and $0.08 \mathrm{~m}$ sections). The remaining two soil columns were subjected to the second and third evaporation levels until soil moisture content reduced by $30 \%$, and $45 \%$ depletion from soil field capacity. Then, the soil columns were also excluded for soil moisture determination in a similar manner applied to the first one. During all evaporation levels, soil, air temperatures were recorded every one minute using data acquisition system. The recorded data were averaged for each hour period. Also, the evaporation from the water column was recorded for every stage. This described experimental setup was conducted twice, during summer 2012 and winter 2013, to detect the effect of treatments under different climatic conditions.

\section{Results and Discussions}

\section{Soil temperature regime of Ismailia sandy soils}

The changes in sandy soil temperatures with soil moisture contents and climatic conditions were investigated. The different climatic conditions were maintained by running the same experimental setup and procedures during August, 2012 for summer conditions and during January and February, 2013 for winter conditions. It was found that during summer, the maximum weighted average soil temperature recorded was $42.5{ }^{\circ} \mathrm{C}$ on August, 13, 2012. The minimum weighted average soil temperature in

Egypt. J. Soil Sci. 56, No. 2 (2016) 
summer was also recorded at the same day, it was $26.6{ }^{\circ} \mathrm{C}$. So, the mean weighted average of soil summer temperature based on the period of measurement for Ismailia sandy soil was $34.5{ }^{\circ} \mathrm{C}$. During the winter, the maximum weighted average soil temperature recorded on February, 8, 2013 and was $27.0{ }^{\circ} \mathrm{C}$. Meanwhile, the minimum weighted average soil temperature recorded on February, 3, 2013 and was $16.4{ }^{\circ} \mathrm{C}$. Using the abovementioned two values, the mean weighted average winter temperature based on the period of measurement for Ismailia sandy soil was $21.7^{\circ} \mathrm{C}$. The difference between mean summer and mean winter soil temperatures was 12.8 ${ }^{\circ} \mathrm{C}$. By using these values and according to Soil Survey Stuff (2006), the soil temperature regime of Ismailia sandy soil is Hyperthermic. Knowledge of the soil temperature regime is fundamental to understand the development and formation of specific soils and to classify and map soils in a consistent manner. It is used for locating areas suitable for agricultural crops, managing the soil-plant-water systems in agriculture, and as ecological indicators of plant distributions and wildlife habitats (Mount \& Paetzold, 2002 and Tejedor et al., 2009). The spatial distribution of soil temperature regimes is essential for accurately inventory the soil resource.

One simple statistical parameter to provide a tool for assessment of soil temperature fluctuation was the Mean Absolute Deviation (MAD). The mean absolute deviation of a data set is the average of the absolute deviations from its mean and is a summary statistic of statistical dispersion or variability (Spiegel and Stephen, 1998). It can be calculated from the following equation:

\section{Mean absolute deviation $=\frac{1}{n} \sum_{i=1}^{n}\left|x_{i}-\bar{x}\right|$}

where $\mathrm{n}$ is the number of observations and $\bar{x}$ is the daily average and $\left|x_{i}-\bar{x}\right|$ the absolute value of deviation of $x_{i}$ from $\bar{x}$. The MAD was calculated for the soil temperature measured at the 5 aforementioned depths, the weighted average soil temperature, and air temperature during the summer of 2012 and the winter of 2013. The data presented in Table 2 indicated that, at all soil moisture levels and during both seasons the maximum MAD was obtained for the upper most $2 \mathrm{~cm}$ soil section. It became almost constant with depth at $15 \mathrm{~cm}$. The data also revealed that, at soil moisture levels of $100 \%$ F.C. and $15 \%$ depletion, $\sum$ MAD values were obviously lower than that at 30 and $45 \%$ depletions during the summer.

\section{Effect of soil surface treatments under summer conditions \\ Soil temperature fluctuations}

Effects of aforementioned six treatments on soil temperature fluctuations, measured at five depths from soil surface with four different moisture levels, were presented in Tables 3-6. The results showed that, the greatest fluctuations in soil temperature were found in the uppermost soil section, $1 \mathrm{~cm}$ depth, for all investigated treatments under all soil moisture levels. For such upper layer, the minimum soil temperature was recorded between 6:00 and 9:00 AM, while the maximum temperature was recorded between 13:00 and 17:00 PM. The value of such temperature was damped with depth and its time was lagged. 
TABLE 2. Mean absolute deviation calculated for air and soil temperatures measured at various depths, weighed average soil temperature, $\mathbf{T}_{\mathrm{C}}$, for studied sandy soil

\begin{tabular}{rrrrrrrr}
\hline Depth & $\mathbf{1 ~ c m}$ & $\mathbf{6 ~ c m}$ & $\mathbf{1 5} \mathbf{~ c m}$ & $\mathbf{2 5} \mathbf{~ c m}$ & $\mathbf{3 5} \mathbf{~ c m}$ & $\sum \mathbf{M A D}$ & $\mathbf{T}_{\mathbf{C}}$ \\
\hline \multicolumn{7}{c}{ Moisture level } & \multicolumn{2}{c}{ Summer 2012} \\
\hline FC & 3.07 & 1.89 & 1.82 & 1.85 & 1.84 & 10.47 & $\mathbf{1 . 6 0}$ \\
$15 \% \mathrm{D}$ & 3.80 & 3.12 & 2.61 & 2.61 & 2.61 & 14.75 & $\mathbf{2 . 5 5}$ \\
$30 \% \mathrm{D}$ & 6.10 & 4.85 & 4.85 & 4.85 & 4.85 & 25.50 & $\mathbf{4 . 7 1}$ \\
$45 \% \mathrm{D}$ & 5.71 & 3.10 & 3.34 & 3.34 & 3.34 & 18.83 & $\mathbf{3 . 0 6}$ \\
\hline & \multicolumn{7}{c}{ Winter 2013} \\
\hline FC & 3.06 & 2.43 & 1.84 & 1.83 & 1.79 & 10.95 & $\mathbf{1 . 8 9}$ \\
$15 \% \mathrm{D}$ & 3.49 & 3.10 & 2.72 & 2.67 & 2.59 & 14.57 & $\mathbf{2 . 6 8}$ \\
$30 \% \mathrm{D}$ & 3.43 & 2.83 & 2.61 & 2.59 & 2.58 & 14.04 & $\mathbf{2 . 4 8}$ \\
$45 \% \mathrm{D}$ & 2.45 & 2.08 & 1.99 & 1.99 & 1.97 & 10.48 & $\mathbf{1 . 9 0}$ \\
\hline
\end{tabular}

TABLE 3. Maximum and minimum air and soil temperatures with their corresponding times for different soil depths at $100 \%$ soil field capacity during summer 2012

\begin{tabular}{|c|c|c|c|c|c|c|c|c|}
\hline \multirow[b]{2}{*}{ Treatment } & \multirow[b]{2}{*}{ Date } & \multirow{2}{*}{$\begin{array}{c}\text { Paramet } \\
\text { er }\end{array}$} & \multicolumn{5}{|c|}{ Soil Depth } & \multirow{2}{*}{ Air } \\
\hline & & & $1 \mathrm{~cm}$ & $6 \mathrm{~cm}$ & $15 \mathrm{~cm}$ & $25 \mathrm{~cm}$ & $35 \mathrm{~cm}$ & \\
\hline \multirow{4}{*}{$\begin{array}{l}\text { Transparent } \\
\text { Plastic } \\
\text { Mulch }\end{array}$} & \multirow{4}{*}{ 09-08-12 } & $\mathrm{T}_{\max }$ & 48.5 & 45.2 & 43.2 & 43.0 & 42.8 & 48.6 \\
\hline & & $\mathrm{T}_{\min }$ & 30.5 & 30.3 & 30.2 & 30.0 & 29.8 & 29.0 \\
\hline & & $\mathrm{t}_{\max }$ & $15: 00$ & $16: 00$ & $17: 00$ & 18:00 & 19:00 & 13:00 \\
\hline & & $\mathrm{t}_{\min }$ & $7: 00$ & 9:00 & 9:00 & 10:00 & 11:00 & $6: 00$ \\
\hline \multirow{4}{*}{$\begin{array}{l}\text { Rice Straw } \\
\text { Mulch } 4 \\
\text { Mg ha }^{-1}\end{array}$} & \multirow{4}{*}{ 09-08-12 } & $\mathrm{T}_{\max }$ & 38.9 & 38.5 & 38.3 & 38.2 & 38.0 & 48.6 \\
\hline & & $\mathrm{T}_{\min }$ & 31.9 & 32.4 & 32.7 & 32.6 & 32.4 & 29.0 \\
\hline & & $\mathrm{t}_{\max }$ & $14: 00$ & $15: 00$ & $17: 00$ & 18:00 & 19:00 & 13:00 \\
\hline & & $\mathrm{t}_{\min }$ & $8: 00$ & 9:00 & $10: 00$ & 11:00 & 11:00 & $6: 00$ \\
\hline \multirow{4}{*}{$\begin{array}{l}\text { Rice Straw } \\
\text { Mulch } 8 \\
\text { Mg ha }^{-1}\end{array}$} & \multirow{4}{*}{ 09-08-12 } & $\mathrm{T}_{\max }$ & 37.8 & 37.6 & 37.4 & 37.4 & 37.2 & 48.6 \\
\hline & & $\mathrm{T}_{\min }$ & 31.8 & 31.7 & 31.5 & 31.9 & 31.7 & 29.0 \\
\hline & & $\mathrm{t}_{\max }$ & $15: 00$ & $16: 00$ & $18: 00$ & 19:00 & 19:00 & 13:00 \\
\hline & & $\mathrm{t}_{\min }$ & 7:00 & 9:00 & 9:00 & 9:00 & 9:00 & 6:00 \\
\hline Bentonite 16 & \multirow{4}{*}{ 09-08-12 } & $\mathrm{T}_{\max }$ & 40.4 & 40.0 & 39.8 & 39.7 & 39.6 & 48.6 \\
\hline \multirow{3}{*}{$\begin{array}{c}\mathrm{Mg} \mathrm{ha}^{-1} \text { in top } \\
10 \mathrm{~cm}^{2} \text { soil } \\
\text { layer }\end{array}$} & & $\mathrm{T}_{\min }$ & 29.9 & 31.9 & 31.9 & 32.8 & 32.6 & 29.0 \\
\hline & & $\mathrm{t}_{\max }$ & $14: 00$ & $15: 00$ & $16: 00$ & 18:00 & 20:00 & 13:00 \\
\hline & & $\mathrm{t}_{\min }$ & $7: 00$ & 9:00 & $10: 00$ & $10: 00$ & 11:00 & $6: 00$ \\
\hline \multirow{4}{*}{$\begin{array}{l}\text { Bentonite } 16 \\
\mathrm{Mg} \mathrm{ha}^{-1} \text { in } \\
\text { top } 20 \mathrm{~cm} \\
\text { soil layer }\end{array}$} & \multirow{4}{*}{ 09-08-12 } & $\mathrm{T}_{\max }$ & 39.7 & 39.6 & 39.3 & 39.4 & 39.2 & 48.6 \\
\hline & & $\mathrm{T}_{\min }$ & 29.5 & 31.2 & 33.0 & 33.2 & 33.0 & 29.0 \\
\hline & & $\mathrm{t}_{\max }$ & 13:00 & $13: 00$ & $16: 00$ & $17: 00$ & 17:00 & 13:00 \\
\hline & & $\mathrm{t}_{\min }$ & 7:00 & 8:00 & 9:00 & 11:00 & 11:00 & $6: 00$ \\
\hline \multirow{4}{*}{ Control } & \multirow{4}{*}{ 09-08-12 } & $\mathrm{T}_{\max }$ & 39.8 & 39.0 & 38.8 & 38.4 & 38.3 & 48.6 \\
\hline & & $\mathrm{T}_{\min }$ & 28.2 & 32.3 & 32.2 & 32.0 & 31.8 & 29.0 \\
\hline & & $\mathrm{t}_{\max }$ & 13:00 & $18: 00$ & 19:00 & 20:00 & 21:00 & 13:00 \\
\hline & & $\mathrm{t}_{\text {min }}$ & 7:00 & 11:00 & $12: 00$ & $12: 00$ & $14: 00$ & 6:00 \\
\hline
\end{tabular}

Egypt. J. Soil Sci. 56, No. 2 (2016) 
TABLE 4. Maximum and minimum air and soil temperatures with their corresponding times for different soil depths at $15 \%$ depletion from soil field capacity during summer 2012

\begin{tabular}{|c|c|c|c|c|c|c|c|c|}
\hline \multirow[b]{2}{*}{ Treatment } & \multirow[b]{2}{*}{ Date } & \multirow{2}{*}{ Parameter } & \multicolumn{5}{|c|}{ Soil Depth } & \multirow{2}{*}{ Air } \\
\hline & & & $1 \mathrm{~cm}$ & $6 \mathrm{~cm}$ & $15 \mathrm{~cm}$ & $25 \mathrm{~cm}$ & $35 \mathrm{~cm}$ & \\
\hline \multirow{4}{*}{$\begin{array}{l}\text { Transparent } \\
\text { Plastic } \\
\text { Mulch }\end{array}$} & \multirow{4}{*}{$\begin{array}{c}13-8- \\
12\end{array}$} & $\mathrm{~T}_{\max }$ & 48.1 & 42.4 & 42.3 & 42.1 & 42.0 & 58.6 \\
\hline & & $\mathrm{T}_{\min }$ & 28.6 & 29.7 & 29.6 & 29.4 & 29.3 & 33.7 \\
\hline & & $\mathrm{t}_{\max }$ & $15: 00$ & $18: 00$ & 18:00 & 19:00 & $20: 00$ & $14: 00$ \\
\hline & & $\mathrm{t}_{\min }$ & $7: 00$ & 9:00 & 9:00 & 10:00 & 11:00 & $7: 00$ \\
\hline \multirow{4}{*}{$\begin{array}{c}\text { Rice Straw } \\
\text { Mulch } 4 \\
\text { Mg ha }^{-1}\end{array}$} & \multirow{4}{*}{$\begin{array}{c}11-8- \\
12\end{array}$} & $\mathrm{~T}_{\max }$ & 38.6 & 38.5 & 38.1 & 38.0 & 37.8 & 47.5 \\
\hline & & $\mathrm{T}_{\min }$ & 31.3 & 32.2 & 32.0 & 31.9 & 31.7 & 29.7 \\
\hline & & $\mathrm{t}_{\max }$ & $17: 00$ & $18: 00$ & $19: 00$ & $19: 00$ & 19:00 & $13: 00$ \\
\hline & & $\mathrm{t}_{\min }$ & 9:00 & 10:00 & $12: 00$ & 11:00 & $12: 00$ & $6: 00$ \\
\hline \multirow{4}{*}{$\begin{array}{l}\text { Rice Straw } \\
\text { Mulch } 8 \\
\text { Mg ha }^{-1}\end{array}$} & \multirow{4}{*}{$\begin{array}{c}13-8- \\
12\end{array}$} & $\mathrm{~T}_{\max }$ & 46.6 & 41.2 & 40.0 & 39.7 & 39.6 & 58.6 \\
\hline & & $\mathrm{T}_{\min }$ & 30.8 & 31.6 & 30.8 & 30.6 & 30.4 & 33.7 \\
\hline & & $\mathrm{t}_{\max }$ & $16: 00$ & $17: 00$ & $17: 00$ & $18: 00$ & $19: 00$ & $14: 00$ \\
\hline & & $\mathrm{t}_{\min }$ & $8: 00$ & $9: 00$ & $9: 00$ & $9: 00$ & $10: 00$ & $7: 00$ \\
\hline \multirow{4}{*}{$\begin{array}{l}\text { Bentonite } \\
16 \mathrm{Mg} \mathrm{ha}^{-1} \\
\text { in top } 10 \\
\mathrm{~cm} \text { soil } \\
\text { layer }\end{array}$} & \multirow{4}{*}{$\begin{array}{c}10-8- \\
12\end{array}$} & $T_{\max }$ & 40.7 & 40.3 & 40.0 & 39.9 & 39.7 & 46.6 \\
\hline & & $\mathrm{T}_{\min }$ & 28.8 & 30.1 & 30.8 & 30.7 & 30.5 & 29.2 \\
\hline & & $\mathrm{t}_{\max }$ & $14: 00$ & $16: 00$ & $18: 00$ & $19: 00$ & $20: 00$ & $13: 00$ \\
\hline & & $\mathrm{t}_{\min }$ & 7:00 & $8: 00$ & 9:00 & 9:00 & 11:00 & 7:00 \\
\hline \multirow{4}{*}{$\begin{array}{l}\text { Bentonite } \\
16 \mathrm{Mg} \mathrm{ha}^{-1} \\
\text { in top } 20 \\
\mathrm{~cm} \text { soil } \\
\text { layer }\end{array}$} & \multirow{4}{*}{$\begin{array}{c}10-8- \\
12\end{array}$} & $\mathrm{~T}_{\max }$ & 41.1 & 39.6 & 39.5 & 39.2 & 39.0 & 46.6 \\
\hline & & $\mathrm{T}_{\min }$ & 29.6 & 29.7 & 30.7 & 31.7 & 31.4 & 29.2 \\
\hline & & $\mathrm{t}_{\max }$ & $15: 00$ & $16: 00$ & 17:00 & 17:00 & 17:00 & $13: 00$ \\
\hline & & $\mathrm{t}_{\min }$ & 7:00 & 8:00 & 9:00 & 9:00 & 9:00 & 7:00 \\
\hline \multirow{4}{*}{ Control } & \multirow{4}{*}{$\begin{array}{c}10-8- \\
12\end{array}$} & $\mathrm{~T}_{\max }$ & 42.5 & 40.7 & 39.6 & 39.4 & 39.2 & 46.6 \\
\hline & & $\mathrm{T}_{\min }$ & 28.2 & 29.6 & 31.0 & 30.7 & 30.6 & 29.2 \\
\hline & & $t_{\max }$ & $15: 00$ & $15: 00$ & 18:00 & $19: 00$ & 20:00 & $13: 00$ \\
\hline & & $t_{\min }$ & $7: 00$ & 7:00 & $8: 00$ & $9: 00$ & $10: 00$ & $7: 00$ \\
\hline
\end{tabular}

TABLE 5. Maximum and minimum air and soil temperatures with their corresponding times for different soil depths at $30 \%$ depletion from soil field capacity during summer 2012

\begin{tabular}{|c|c|c|c|c|c|c|c|c|}
\hline \multirow[b]{2}{*}{ Treatment } & \multirow[b]{2}{*}{ Date } & \multicolumn{3}{|l|}{ Paramete } & \multicolumn{3}{|c|}{ Soil Depth } & \multirow{2}{*}{ Air } \\
\hline & & $\mathbf{r}$ & $1 \mathrm{~cm}$ & $6 \mathrm{~cm}$ & $15 \mathrm{~cm}$ & $25 \mathrm{~cm}$ & $35 \mathrm{~cm}$ & \\
\hline \multirow{4}{*}{$\begin{array}{c}\text { Transparent } \\
\text { Plastic } \\
\text { Mulch }\end{array}$} & \multirow{4}{*}{$\begin{array}{c}17-08- \\
12\end{array}$} & $\mathrm{~T}_{\max }$ & 46.6 & 41.8 & 41.3 & 41.2 & 41.0 & 55.0 \\
\hline & & $\mathrm{T}_{\min }$ & 27.7 & 28.4 & 30.0 & 29.9 & 29.7 & 33.6 \\
\hline & & $\mathrm{t}_{\max }$ & $15: 00$ & $18: 00$ & 19:00 & 20:00 & 21:00 & $15: 00$ \\
\hline & & $\mathrm{t}_{\min }$ & $7: 00$ & 9:00 & 9:00 & $10: 00$ & 11:00 & $7: 00$ \\
\hline \multirow{4}{*}{$\begin{array}{c}\text { Rice Straw } \\
\text { Mulch } 4 \\
\text { Mg ha }^{-1}\end{array}$} & \multirow{4}{*}{$\begin{array}{c}14-08- \\
12\end{array}$} & $\mathrm{~T}_{\max }$ & 40.2 & 38.9 & 38.5 & 38.3 & 38.2 & 53.2 \\
\hline & & $\mathrm{T}_{\min }$ & 30.8 & 31.0 & 31.2 & 31.0 & 30.9 & 33.5 \\
\hline & & $\mathrm{t}_{\max }$ & $15: 00$ & $17: 00$ & $18: 00$ & 20:00 & 20:00 & $15: 00$ \\
\hline & & $\mathrm{t}_{\min }$ & 9:00 & 9:00 & $8: 00$ & $8: 00$ & $8: 00$ & $7: 00$ \\
\hline \multirow{4}{*}{$\begin{array}{c}\text { Rice Straw } \\
\text { Mulch } 8 \\
\text { Mg ha }^{-1}\end{array}$} & \multirow{4}{*}{$\begin{array}{c}17-08- \\
12\end{array}$} & $\mathrm{~T}_{\max }$ & 44.6 & 39.7 & 38.3 & 37.6 & 37.5 & 55.0 \\
\hline & & $\mathrm{T}_{\min }$ & 29.5 & 29.5 & 29.4 & 29.4 & 29.3 & 33.6 \\
\hline & & $\mathrm{t}_{\max }$ & $15: 00$ & $16: 00$ & $16: 00$ & $17: 00$ & 19:00 & $15: 00$ \\
\hline & & $\mathrm{t}_{\min }$ & $6: 00$ & 7:00 & $8: 00$ & 7:00 & 9:00 & 7:00 \\
\hline \multirow{4}{*}{$\begin{array}{l}\text { Bentonite } 16 \\
\mathrm{Mg} \mathrm{ha}^{-1} \text { in } \\
\text { top } 10 \mathrm{~cm} \\
\text { soil layer }\end{array}$} & \multirow{4}{*}{$\begin{array}{c}13-08- \\
12\end{array}$} & $\mathrm{~T}_{\max }$ & 48.2 & 41.0 & 38.0 & 37.9 & 37.7 & 58.6 \\
\hline & & $\mathrm{T}_{\min }$ & 31.6 & 32.2 & 32.0 & 31.8 & 31.7 & 33.7 \\
\hline & & $t_{\max }$ & $15: 00$ & $16: 00$ & $17: 00$ & $18: 00$ & $18: 00$ & $14: 00$ \\
\hline & & $\mathrm{t}_{\min }$ & 7:00 & $8: 00$ & $8: 00$ & 9:00 & 9:00 & 7:00 \\
\hline \multirow{4}{*}{$\begin{array}{l}\text { Bentonite } 16 \\
\mathrm{Mg} \mathrm{ha}^{-1} \mathrm{in} \\
\text { top } 20 \mathrm{~cm} \\
\text { soil layer }\end{array}$} & \multirow{4}{*}{$\begin{array}{c}13-08- \\
12\end{array}$} & $\mathrm{~T}_{\max }$ & 42.5 & 42.0 & 41.0 & 40.9 & 40.7 & 58.6 \\
\hline & & $\mathrm{T}_{\min }$ & 32.1 & 32.1 & 31.4 & 31.2 & 31.1 & 33.7 \\
\hline & & $\mathrm{t}_{\max }$ & $15: 00$ & $16: 00$ & $17: 00$ & 18:00 & 18:00 & $15: 00$ \\
\hline & & $\mathrm{t}_{\min }$ & 5:00 & $6: 00$ & $8: 00$ & 9:00 & 9:00 & $7: 00$ \\
\hline \multirow{4}{*}{ Control } & \multirow{4}{*}{$\begin{array}{c}13-08- \\
12\end{array}$} & $\mathrm{~T}_{\max }$ & 43.9 & 43.1 & 42.9 & 42.7 & 42.6 & 58.6 \\
\hline & & $\mathrm{T}_{\min }$ & 24.1 & 26.6 & 26.4 & 26.2 & 26.1 & 33.7 \\
\hline & & $\mathrm{t}_{\max }$ & $13: 00$ & $15: 00$ & $15: 00$ & $16: 00$ & $17: 00$ & $14: 00$ \\
\hline & & $\mathrm{t}_{\min }$ & $6: 00$ & $8: 00$ & $8: 00$ & 9:00 & 10:00 & $7: 00$ \\
\hline
\end{tabular}


TABLE 6. Maximum and minimum air and soil temperatures with their corresponding times for different soil depths at $45 \%$ depletion from soil field capacity during summer 2012

\begin{tabular}{|c|c|c|c|c|c|c|c|c|}
\hline \multirow[b]{2}{*}{ Treatment } & \multirow[b]{2}{*}{ Date } & \multirow{2}{*}{ Parameter } & \multicolumn{5}{|c|}{ Soil Depth } & \multirow{2}{*}{ Air } \\
\hline & & & $1 \mathrm{~cm}$ & $6 \mathrm{~cm}$ & $15 \mathrm{~cm}$ & $25 \mathrm{~cm}$ & $35 \mathrm{~cm}$ & \\
\hline \multirow{4}{*}{$\begin{array}{c}\text { Transparent } \\
\text { Plastic } \\
\text { Mulch }\end{array}$} & \multirow{4}{*}{$\begin{array}{c}27-08- \\
12\end{array}$} & $\mathrm{~T}_{\max }$ & 59.4 & 57.4 & 54.7 & 52.5 & 52.3 & 67.5 \\
\hline & & $\mathrm{T}_{\min }$ & 27.4 & 25.9 & 26.7 & 26.3 & 26.2 & 30.7 \\
\hline & & $\mathrm{t}_{\max }$ & $13: 00$ & $14: 00$ & $15: 00$ & $15: 00$ & $16: 00$ & $14: 00$ \\
\hline & & $\mathrm{t}_{\min }$ & $7: 00$ & $7: 00$ & $8: 00$ & 8:00 & $9: 00$ & $7: 00$ \\
\hline \multirow{4}{*}{$\begin{array}{c}\text { Rice Straw } \\
\text { Mulch } 4 \\
\text { Mg ha }^{-1}\end{array}$} & \multirow{4}{*}{$\begin{array}{c}25-08- \\
12\end{array}$} & $\mathrm{~T}_{\max }$ & 49.2 & 40.8 & 38.3 & 36.2 & 36.1 & 67.6 \\
\hline & & $\mathrm{T}_{\min }$ & 34.9 & 33.3 & 31.8 & 30.6 & 30.5 & 31.5 \\
\hline & & $\mathrm{t}_{\max }$ & $14: 00$ & $17: 00$ & $17: 00$ & 18:00 & 19:00 & $13: 00$ \\
\hline & & $\mathrm{t}_{\min }$ & 5:00 & 9:00 & 9:00 & 10:00 & 11:00 & $6: 00$ \\
\hline \multirow{4}{*}{$\begin{array}{c}\text { Rice Straw } \\
\text { Mulch } 8 \\
\mathrm{Mg} \mathrm{ha}^{-1}\end{array}$} & \multirow{4}{*}{$\begin{array}{c}27-08- \\
12\end{array}$} & $\mathrm{~T}_{\max }$ & 55.0 & 48.8 & 46.7 & 46.4 & 46.3 & 67.5 \\
\hline & & $\mathrm{T}_{\min }$ & 27.5 & 26.9 & 26.7 & 26.5 & 26.3 & 30.7 \\
\hline & & $\mathrm{t}_{\max }$ & $14: 00$ & $15: 00$ & $16: 00$ & $17: 00$ & $18: 00$ & $14: 00$ \\
\hline & & $\mathrm{t}_{\min }$ & 7:00 & $6: 00$ & 7:00 & 8:00 & 9:00 & $7: 00$ \\
\hline \multirow{4}{*}{$\begin{array}{l}\text { Bentonite } \\
16 \mathrm{Mg} \mathrm{ha}^{-1} \\
\text { in top } 10 \\
\text { cm soil } \\
\text { layer }\end{array}$} & \multirow{4}{*}{$\begin{array}{c}\text { 21-08- } \\
12\end{array}$} & $\mathrm{~T}_{\max }$ & 46.9 & 46.0 & 42.1 & 39.6 & 36.7 & 54.7 \\
\hline & & $\mathrm{T}_{\min }$ & 29.2 & 31.8 & 31.5 & 31.0 & 29.8 & 32.5 \\
\hline & & $\mathrm{t}_{\max }$ & $15: 00$ & $16: 00$ & $18: 00$ & $17: 00$ & $17: 00$ & $15: 00$ \\
\hline & & $\mathrm{t}_{\min }$ & 7:00 & 7:00 & 7:00 & $8: 00$ & $8: 00$ & 7:00 \\
\hline \multirow{4}{*}{$\begin{array}{c}\text { Bentonite } \\
16 \mathrm{Mg} \mathrm{ha}^{-1} \\
\text { in top } 20 \\
\mathrm{~cm} \text { soil } \\
\text { layer }\end{array}$} & \multirow{4}{*}{$\begin{array}{c}\text { 21-08- } \\
12\end{array}$} & $\mathrm{~T}_{\max }$ & 44.2 & 43.0 & 42.0 & 41.9 & 41.7 & 54.7 \\
\hline & & $\mathrm{T}_{\min }$ & 33.0 & 33.2 & 32.5 & 32.3 & 32.2 & 32.5 \\
\hline & & $\mathrm{t}_{\max }$ & $15: 00$ & $16: 00$ & $18: 00$ & 19:00 & 19:00 & $14: 00$ \\
\hline & & $\mathrm{t}_{\min }$ & $6: 00$ & $6: 00$ & 9:00 & $10: 00$ & $12: 00$ & 7:00 \\
\hline \multirow{4}{*}{ Control } & \multirow{4}{*}{$\begin{array}{c}21-08- \\
12\end{array}$} & $\mathrm{~T}_{\max }$ & 41.9 & 41.5 & 41.2 & 41.1 & 40.9 & 54.7 \\
\hline & & $\mathrm{T}_{\min }$ & 23.2 & 31.3 & 29.3 & 29.1 & 29.0 & 32.5 \\
\hline & & $\mathrm{t}_{\max }$ & $15: 00$ & 18:00 & $19: 00$ & 20:00 & 21:00 & $15: 00$ \\
\hline & & $\mathrm{t}_{\min }$ & $6: 00$ & 8:00 & 9:00 & $10: 00$ & 11:00 & $7: 00$ \\
\hline
\end{tabular}

The obtained amplitude values did not have a specified trend. However, they were increased as soil moisture decreased, but the differences were not homogenous. This could be attributed to the different air temperatures during the four days of observation, so the soil columns were subjected to different ambient temperatures. To overcome this situation, a relative amplitude, R.A., was introduced. Its value can be calculated by dividing the amplitude of soil temperature by the amplitude of air temperature. The relative amplitude R.A. of the uppermost soil temperatures were $0.918,0.357,0.306,0.536,0.520$, and 0.592 for the treatments $\mathrm{TP}, \mathrm{R}_{4}, \mathrm{R}_{8}, \mathrm{~B}_{10}, \mathrm{~B}_{20}$, and $\mathrm{C}$, respectively, at whole soil field capacity. Its values at $15 \%$ depletions were $0.783,0.410,0.635,0.684$, 0.661 , and 0.823 for the investigated treatments, respectively. At $30 \%$ depletion they were $0.883,0.477,0.706,0.667,0.418$, and 0.795 , respectively. Also, the R.A. at $45 \%$ depletion were $0.870,0.396,0.747,0.797,0.505$, and 0.842 for the previous treatments, respectively. The values indicated that, the lowest R.A. was recorded under rice straw mulch treatment.

August, 9, 2012 was a promising day to evaluate the effect of the above mentioned treatments under the same soil moisture level and climatic conditions. Therefore, the abovementioned R.A. had the same trend as well as the absolute fluctuation. At that day the soil moisture was at a whole field capacity. The maximum

Egypt. J. Soil Sci. 56, No. 2 (2016) 
air temperature was $48.6^{\circ} \mathrm{C}$ and the minimum was $29.0^{\circ} \mathrm{C}$, so the fluctuation in air temperature was $19.6{ }^{\circ} \mathrm{C}$. Where maximum fluctuation of soil temperature occurred in the uppermost soil layer, so it is more convenient to determine the effects of the investigated treatments on the temperature fluctuation of such layer. The greatest fluctuation in soil temperature was $18.0{ }^{\circ} \mathrm{C}$ recorded under TP treatment with maximum of 48.5 and minimum of $30.5^{\circ} \mathrm{C}$. The effects of transparent plastic in rising soil temperature were early studied by Emmert (1957). Munguia et al. (1999) reported that the net radiation is higher in the plastic mulched field than that in the non-plastic mulched field. He attributed that to the substantial effect of the spectral properties of the plastic mulch on the short and long wave radiations. Yaghi et al. (2013) found an increase in the soil temperature by $6.4,5.9$ and $5.6{ }^{\circ} \mathrm{C}$, at soil surface, at $5 \mathrm{~cm}$ and $10 \mathrm{~cm}$ soil depth, respectively, under transparent plastic mulching.

On the other hand, the smallest fluctuation was $6.0{ }^{\circ} \mathrm{C}$ for $\mathrm{R}_{8}$ treatment with maximum and minimum values of 37.8 and $31.8{ }^{\circ} \mathrm{C}$, respectively. Increasing the application rate of rice straw from 4 to $8 \mathrm{Mg} \mathrm{ha}^{-1}$ reduced the maximum soil temperature from 38.9 to $37.8^{\circ} \mathrm{C}$ where the minimum values were approximately equaled. Consequently, fluctuation of the uppermost soil layer was reduced from 7.0 to $6.0{ }^{\circ} \mathrm{C}$ with doubling the application rate of rice straw from 4 to $8 \mathrm{Mg} \mathrm{ha}^{-1}$. The rice straw mulch depressed soil temperature because it has a higher albedo and a lower thermal conductivity than the bare soil. Consequently, it reduces the solar energy reaching the soil surface and reduces temperature increases during warm conditions as reported by Horton et al. (1996). Zhang et al. (2009) observed that, soil temperature under $8 \mathrm{Mg} \mathrm{ha}^{-1}$ straw mulch was lower than nonmulched soil by about $4.0^{\circ} \mathrm{C}$ during the warm season.

Incorporating bentonite with soil had a little effect on soil temperature fluctuation. It was 10.5 for B10 and 10.2 for B20 treatments compared to $11.6^{\circ} \mathrm{C}$ for the control. The obtained results for the effect of bentonite incorporation on soil temperature was contradicted with that reported by Zvomuya et al. (2008). They concluded that, bentonite application at $16 \mathrm{Mg} \mathrm{ha}^{-1}$ as drilling mud resulted in an increase in mean daily soil temperature. Such disagreement with this result could be ascribed to different application procedure, incorporation and surface spraying as mud. Also, the study of Zvomuya et al. (2008) was conducted at the cold climate of Canada. The arrangement of the treatments in descending order for the uppermost soil temperature fluctuation was TP, C, $\mathrm{B}_{10}, \mathrm{~B}_{20}, \mathrm{R}_{4}$, and $\mathrm{R}_{8}$ as indicated from Table 3. So it can be concluded that straw mulch was the most efficient treatment in reducing soil temperature fluctuation during the summer conditions of Ismailia, Egypt, when soil moisture content was kept at field capacity. Almost similar trends were found for all the investigated treatments at other soil moisture levels.

To illustrate the effect of the different treatments on soil temperature, the time rates of weighted average soil temperature change $(\Delta T / \Delta t)$ were calculated on August, 9, 2012, where all treatments were at whole field capacity and subjected to the same climatic condition. The values obtained for time rates of soil temperature change during the heating period were $1.43,0.70,0.62,0.72,0.75$, and $0.76{ }^{\circ} \mathrm{C} \mathrm{h}^{-1}$ for $\mathrm{TP}, \mathrm{R}_{4}, \mathrm{R}_{8}, \mathrm{~B}_{10}, \mathrm{~B}_{20}$, and $\mathrm{C}$ treatments, respectively. The maximum time rate of heat gain was recorded under TP treatment. This could be 
attributed to the fact that, transparent plastic mulch allow the incoming shortwave radiation to strike the soil surface. It reducing the loss of such received energy by evaporation, long-wave radiation, and conduction to the adjacent air layer, which leads to raising the rate of heat gain by these covered soil compared to other treatments (Wu et al., 2007). On the other hand, the smallest time rate of temperature rising was obtained under R8 treatment. Most likely because it has a higher albedo and lower thermal conductivity than uncovered soil, therefore, straw mulch reduces the solar energy reaching the soil and so reduces temperature rising during the warm conditions (Horton et al., 1996). However, bentonite incorporation resulted in a small decrease in time rate of soil temperature rising. Such decrease was more when the incorporation of bentonite was made in the uppermost $10 \mathrm{~cm}$ soil layer, and could be attributed to the presence of much amount of water to be evaporated at the soil surface.

The time rates of soil temperature falling during two cooling periods, from 0:00 $\mathrm{AM}$ to time of minimum temperature and from time of maximum temperature to 0:00 $\mathrm{AM}$ on next day, were also calculated for all treatments. Its obtained values were $0.78,-0.39,-0.49,-0.50,-0.53$, and $-0.51{ }^{\circ} \mathrm{C} \mathrm{h}^{-1}$ for $\mathrm{TP}, \mathrm{R}_{4}, \mathrm{R}_{8}, \mathrm{~B}_{10}, \mathrm{~B}_{20}$, and $\mathrm{C}$ treatments, respectively. The highest value was obtained under TP treatment while the lowest value was obtained under $\mathrm{R}_{4}$ and it was lower than that obtained for $\mathrm{R}_{8}$. Shinde (1997) reported that increasing the application rate of straw mulch increasing the outgoing from the soil. In regard to bentonite incorporation, such effect was trifling.

\section{Soil moisture evaporation}

In order to evaluate the effect of the investigated treatments on water evaporation from soil, evaporation rate, in $\mathrm{g}$ water per soil column per day, was calculated. Figure 1 elucidates the changes in evaporation rates, in $g$ water per soil column per day, as a function of time, days. All investigated treatments nearly have the same manner of increasing evaporation rate to reach its maximum values then starts to decrease again.

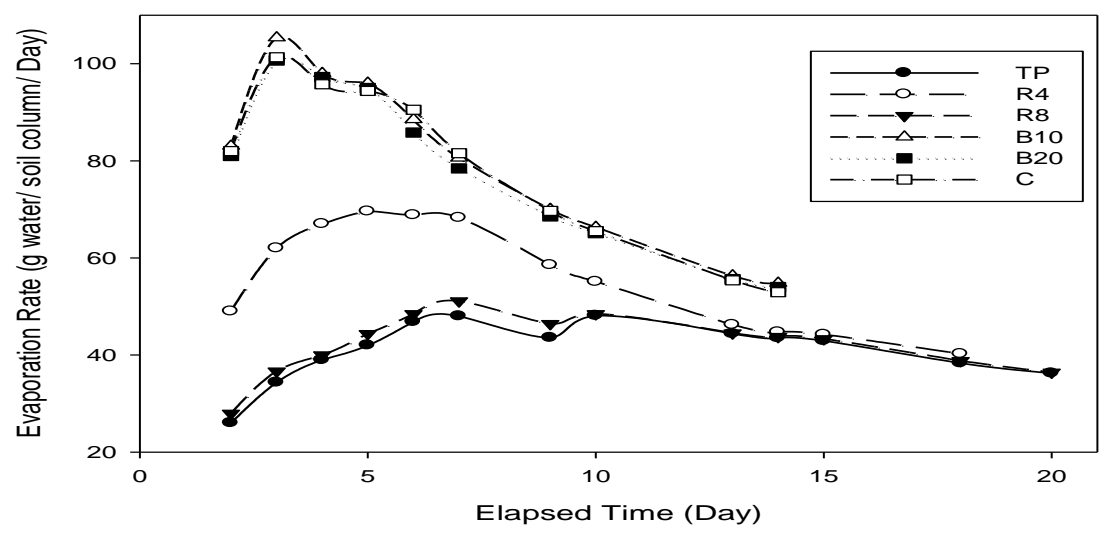

Fig.1. Effect of different soil surface treatments on evaporation rate for Ismailia sandy soil during summer 2012

Egypt. J. Soil Sci. 56, No. 2 (2016) 
Such behavior in evaporation rate did not agreed with that described by Hillel (2004) except for the first stage, which stated that, the draying process has been observed to occur in three recognizable stages, namely: constant rate stage, falling rate stage, and slow rate stage. The duration of each stage lasts depends on the intensity of metrological factors that determine atmospheric evaporativity as well as on the depth and the conductive properties of the soil itself. This ideal manner in evaporation process from non-cultivated soil may not be accomplished. The changes in the climatic conditions during the first seven days of observation were the reason that leading to increase evaporation rate rather than keeping it constant. Hillel (2004) referred to the constant rate stage as weather controlled stage, indicating the high effect of climatic condition on this stage. He also concluded that constant-rate stage of evaporation really makes sense only in connection with laboratory experiments under constant evaporativity. In natural, conditions evaporativity varies continually due to changes in the intensity of incoming radiation during the day-night cycles, while the other two stages, falling rate and slow rate, were observed as showed in Fig.1.

The treatments $B_{10}, B_{20}$, and $C$ slightly vary in evaporation rate. They recorded the highest values, while TP and $\mathrm{R}_{8}$ treatments were similar but recorded the lowest evaporation rate values. The effect of plastic mulch in reducing water evaporation was reported by Yang et al. (2012) and Liu et al. (2013). They concluded that, transparent plastic mulch could prevent about $93 \%$ of soil water evaporation, so the soil moisture conservation was improved. In the same context Sarkar et al. (2007) reported that, straw mulch forms a barrier to the evaporating soil surface and alters micro-climate which acts as a driving force for evaporation. Because of this reason, soil moisture depleted at a slower rate from the top soil layer under straw mulch. For bentonite treatments, Sheta et al. (2006) reported that, bentonite application alters the water evaporation from soil when its application rate exceeds $5 \%$. In our study the highest application rate was $1 \%$.

The soil moisture distributions along the soil column were determined at the three investigated depletion levels, the obtained results were presented in Table 7. Data showed that, all investigated treatments exhibited very similar moisture distribution patterns at $15 \%$ and $45 \%$ depletion levels. However, at the intermediate depletion level, $30 \%$, and especially for the upper soil sections, TP treatment recorded the highest soil moisture content followed by $R_{4}$ and $R_{8}$ treatments. On the other hand, the treatments $\mathrm{B}_{10}, \mathrm{~B}_{20}$, and $\mathrm{C}$ recorded the lowest soil moisture contents as it approaches air dry conditions at the soil surface. The reason for these findings may be the slow evaporation rates obtained for TP, $\mathrm{R}_{8}$, and $\mathrm{R}_{4}$ treatments which allow more time for soil moisture redistributions along the soil columns. 
TABLE 7. Effect of bentonite incorporation and surface mulching on soil moisture distribution at different depletion levels for Ismailia sandy soil during summer 2012

\begin{tabular}{|c|c|c|c|c|c|c|}
\hline Treatment & TP & $\mathbf{R}_{\mathbf{4}}$ & $\mathbf{R}_{\mathbf{8}}$ & $\mathbf{B}_{10}$ & $\mathbf{B}_{20}$ & $\mathbf{C}$ \\
\hline Depth $(\mathrm{cm})$ & \multicolumn{6}{|c|}{ At $15 \%$ Depletion from Soil Field Capacity } \\
\hline 1 & 0.0984 & 0.0858 & 0.0974 & 0.1082 & 0.0968 & 0.0868 \\
\hline 6 & 0.1008 & 0.1043 & 0.1134 & 0.1090 & 0.1035 & 0.1049 \\
\hline 15 & 0.1192 & 0.1202 & 0.1226 & 0.1178 & 0.1166 & 0.1163 \\
\hline 25 & 0.1302 & 0.1332 & 0.1244 & 0.1253 & 0.1355 & 0.1248 \\
\hline \multirow[t]{2}{*}{35} & 0.1445 & 0.1447 & 0.1333 & 0.1426 & 0.1422 & 0.1436 \\
\hline & \multicolumn{6}{|c|}{ At 30\% Depletion from Soil Field Capacity } \\
\hline 1 & 0.0953 & 0.0767 & 0.0714 & 0.0204 & 0.0248 & 0.0267 \\
\hline 6 & 0.0926 & 0.0950 & 0.0849 & 0.0830 & 0.0924 & 0.0837 \\
\hline 15 & 0.1022 & 0.1026 & 0.1034 & 0.1053 & 0.1054 & 0.0943 \\
\hline 25 & 0.1049 & 0.1107 & 0.1126 & 0.1153 & 0.1119 & 0.1132 \\
\hline \multirow[t]{2}{*}{35} & 0.1234 & 0.1200 & 0.1239 & 0.1278 & 0.1253 & 0.1220 \\
\hline & \multicolumn{6}{|c|}{ At $45 \%$ Depletion from Soil Field Capacity } \\
\hline 1 & 0.0152 & 0.0143 & 0.0150 & 0.0117 & 0.0110 & 0.0071 \\
\hline 6 & 0.0393 & 0.0437 & 0.0397 & 0.0422 & 0.0373 & 0.0355 \\
\hline 15 & 0.0857 & 0.0848 & 0.0851 & 0.0876 & 0.0856 & 0.0811 \\
\hline 25 & 0.1043 & 0.1026 & 0.1038 & 0.1011 & 0.1059 & 0.1084 \\
\hline 35 & 0.1130 & 0.1124 & 0.1125 & 0.1107 & 0.1129 & 0.1124 \\
\hline
\end{tabular}

\section{Effect of soil surface treatments under winter conditions}

Soil temperature fluctuation

The effects of previously described six treatments on soil temperature fluctuation under winter conditions of 2013 were also investigated. Data of soil temperature fluctuations measured at five depths for the soil at four different moisture levels of the investigated treatments were presented in Tables $8-11$. The obtained results revealed that, the greatest fluctuations in soil temperature were detected in the uppermost $1 \mathrm{~cm}$ soil section. For such depth the minimum soil temperature were recorded between 7:00 and 9:00 AM, while the maximum temperatures were recorded between 14:00 and 17:00 PM. Values of soil temperature were damped with depth and its times were lagged. The damping of temperature with depth and time lag of soil temperature are a natural phenomenon in soil temperature behavior. The relative amplitude R.A. of the uppermost soil temperatures were $0.768,0.573,0.427,0.652,0.591$, and 0.677 for the treatments $\mathrm{TP}, \mathrm{R}_{4}, \mathrm{R}_{8}, \mathrm{~B}_{10}, \mathrm{~B}_{20}$, and $\mathrm{C}$, respectively, at whole soil field capacity. Its values at $15 \%$ depletions were $2.326,1.471,1.955,1.022,1.611$, and 1.389 for the same treatments, respectively. At 30\% depletion they were 2.722, 1.953, 1.738, 0.989, 1.477, and 1.443, respectively. Also, the R.A. at 45\% depletion was 2.278, 1.403, Egypt. J. Soil Sci. 56, No. 2 (2016) 
$1.737,1.050,1.538$, and 1.175 for the treatments, respectively. The values indicated that, the lowest R.A. was recorded under straw mulch treatment. By comparing the data for R.A. obtained during the summer with that obtained during the winter, it was found that, the R.A. values during the winter were higher than that obtained during the summer for all the investigated treatments. This could be indicated that, the soil temperature amelioration is more necessary during the winter compared to the summer conditions.

TABLE 8. Maximum and minimum air and soil temperatures with their corresponding times for different soil depths at $100 \%$ field capacity during winter 2013

\begin{tabular}{|c|c|c|c|c|c|c|c|c|}
\hline \multirow[b]{2}{*}{ Treatment } & \multirow[b]{2}{*}{ Date } & \multirow{2}{*}{ Parameter } & \multicolumn{5}{|c|}{ Soil Depth } & \multirow{2}{*}{ Air } \\
\hline & & & $1 \mathrm{~cm}$ & $6 \mathrm{~cm}$ & $15 \mathrm{~cm}$ & $25 \mathrm{~cm}$ & $35 \mathrm{~cm}$ & \\
\hline \multirow{4}{*}{$\begin{array}{c}\text { Transparent } \\
\text { Plastic } \\
\text { Mulch }\end{array}$} & \multirow{4}{*}{$26-01-13$} & $\mathrm{~T}_{\max }$ & 27.8 & 27.5 & 27.4 & 27.3 & 27.2 & 28.4 \\
\hline & & $\mathrm{T}_{\min }$ & 15.2 & 16.9 & 19.5 & 19.5 & 19.5 & 12.0 \\
\hline & & $\mathrm{t}_{\max }$ & $14: 00$ & $15: 00$ & $16: 00$ & $17: 00$ & 18:00 & $15: 00$ \\
\hline & & $\mathrm{t}_{\min }$ & 7:00 & 9:00 & $10: 00$ & 11:00 & 10:00 & $6: 00$ \\
\hline \multirow{4}{*}{$\begin{array}{c}\text { Rice Straw } \\
\text { Mulch } 4 \mathrm{Mg} \\
\text { ha }^{-1}\end{array}$} & \multirow{4}{*}{$26-01-13$} & $\mathrm{~T}_{\max }$ & 23.8 & 22.7 & 22.4 & 22.2 & 22.1 & 28.4 \\
\hline & & $\mathrm{T}_{\min }$ & 14.4 & 14.8 & 15.1 & 15.5 & 15.5 & 12.0 \\
\hline & & $\mathrm{t}_{\max }$ & $15: 00$ & $16: 00$ & $17: 00$ & 18:00 & 18:00 & $15: 00$ \\
\hline & & $\mathrm{t}_{\min }$ & 9:00 & 9:00 & $10: 00$ & 10:00 & 11:00 & $6: 00$ \\
\hline \multirow{4}{*}{$\begin{array}{c}\text { Rice Straw } \\
\text { Mulch } 8 \mathrm{Mg} \\
\text { ha }^{-1}\end{array}$} & \multirow{4}{*}{$26-01-13$} & $\mathrm{~T}_{\max }$ & 25.0 & 24.5 & 23.8 & 23.7 & 23.5 & 28.4 \\
\hline & & $\mathrm{T}_{\min }$ & 18.0 & 18.7 & 19.2 & 19.1 & 19.2 & 12.0 \\
\hline & & $\mathrm{t}_{\max }$ & $15: 00$ & $17: 00$ & $18: 00$ & $19: 00$ & 20:00 & $15: 00$ \\
\hline & & $\mathrm{t}_{\min }$ & 8:00 & 8:00 & $10: 00$ & 11:00 & 11:00 & $6: 00$ \\
\hline \multirow{4}{*}{$\begin{array}{l}\text { Bentonite } 16 \\
\mathrm{Mg} \mathrm{ha}^{-1} \text { in } \\
\text { top } 10 \mathrm{~cm} \\
\text { soil layer }\end{array}$} & \multirow{4}{*}{$26-01-13$} & $\mathrm{~T}_{\max }$ & 22.0 & 21.8 & 21.2 & 20.9 & 20.7 & 28.4 \\
\hline & & $\mathrm{T}_{\min }$ & 11.3 & 13.6 & 13.6 & 13.9 & 13.7 & 12.0 \\
\hline & & $\mathrm{t}_{\max }$ & $14: 00$ & $15: 00$ & $16: 00$ & $17: 00$ & 18:00 & $15: 00$ \\
\hline & & $\mathrm{t}_{\text {min }}$ & 7:00 & 8:00 & 9:00 & 10:00 & 11:00 & $6: 00$ \\
\hline \multirow{4}{*}{$\begin{array}{l}\text { Bentonite } 16 \\
\mathrm{Mg} \mathrm{ha}^{-1} \text { in } \\
\text { top } 20 \mathrm{~cm} \\
\text { soil layer }\end{array}$} & \multirow{4}{*}{$26-01-13$} & $\mathrm{~T}_{\max }$ & 21.8 & 21.6 & 21.0 & 20.8 & 20.7 & 28.4 \\
\hline & & $\mathrm{T}_{\min }$ & 12.1 & 13.1 & 13.5 & 13.7 & 13.6 & 12.0 \\
\hline & & $\mathrm{t}_{\max }$ & $14: 00$ & $15: 00$ & $16: 00$ & $17: 00$ & 18:00 & $15: 00$ \\
\hline & & $\mathrm{t}_{\min }$ & 7:00 & 8:00 & 9:00 & $10: 00$ & 11:00 & $6: 00$ \\
\hline \multirow{4}{*}{ Control } & \multirow{4}{*}{$26-01-13$} & $\mathrm{~T}_{\max }$ & 25.4 & 25.3 & 25.2 & 24.6 & 24.4 & 28.4 \\
\hline & & $\mathrm{T}_{\text {min }}$ & 14.3 & 16.5 & 18.6 & 18.4 & 18.5 & 12.0 \\
\hline & & $\mathrm{t}_{\max }$ & $14: 00$ & $15: 00$ & $16: 00$ & $16: 00$ & $17: 00$ & $15: 00$ \\
\hline & & $\mathrm{t}_{\text {min }}$ & 7:00 & $8: 00$ & 9:00 & 9:00 & 10:00 & 6:00 \\
\hline
\end{tabular}


TABLE 9. Maximum and minimum air and soil temperatures with their corresponding times for different soil depths at $15 \%$ depletion from soil field capacity during winter 2013

\begin{tabular}{|c|c|c|c|c|c|c|c|c|}
\hline \multirow[b]{2}{*}{ Treatment } & \multirow[b]{2}{*}{ Date } & \multirow{2}{*}{ Parameter } & \multicolumn{5}{|c|}{ Soil Depth } & \multirow{2}{*}{ Air } \\
\hline & & & $1 \mathrm{~cm}$ & $6 \mathrm{~cm}$ & $15 \mathrm{~cm}$ & $25 \mathrm{~cm}$ & $35 \mathrm{~cm}$ & \\
\hline \multirow{4}{*}{$\begin{array}{c}\text { Transparent } \\
\text { Plastic Mulch }\end{array}$} & \multirow{4}{*}{$15-02-13$} & $\mathrm{~T}_{\text {max }}$ & 27.1 & 25.9 & 25.1 & 24.3 & 24.1 & 21.4 \\
\hline & & $\mathrm{T}_{\text {min }}$ & 17.1 & 17.2 & 17.4 & 17.5 & 17.6 & 17.1 \\
\hline & & $\mathrm{t}_{\max }$ & $14: 00$ & 15:00 & $16: 00$ & 17:00 & 18:00 & 18:00 \\
\hline & & $\mathrm{t}_{\text {min }}$ & 8:00 & 9:00 & 10:00 & 10:00 & 11:00 & 9:00 \\
\hline \multirow{4}{*}{$\begin{array}{c}\text { Rice Straw } \\
\text { Mulch } 4 \text { Mg } \\
\text { ha }^{-1}\end{array}$} & \multirow{4}{*}{ 06-02-13 } & $\mathrm{T}_{\text {max }}$ & 22.2 & 22.0 & 21.7 & 21.5 & 21.4 & 20.8 \\
\hline & & $\mathrm{T}_{\text {min }}$ & 17.2 & 17.5 & 17.6 & 17.5 & 17.4 & 17.4 \\
\hline & & $\mathrm{t}_{\max }$ & $15: 00$ & $16: 00$ & 18:00 & 18:00 & 19:00 & $15: 00$ \\
\hline & & $\mathrm{t}_{\text {min }}$ & 9:00 & 9:00 & 10:00 & 12:00 & 13:00 & $10: 00$ \\
\hline \multirow{4}{*}{$\begin{array}{c}\text { Rice Straw } \\
\text { Mulch } 8 \mathrm{Mg} \\
\text { ha }^{-1}\end{array}$} & \multirow{4}{*}{$08-02-13$} & $\mathrm{~T}_{\max }$ & 32.4 & 29.3 & 28.1 & 28.0 & 27.3 & 24.5 \\
\hline & & $\mathrm{T}_{\text {min }}$ & 15.2 & 15.8 & 16.0 & 16.8 & 17.1 & 15.7 \\
\hline & & $\mathrm{t}_{\max }$ & 14:00 & 15:00 & 16:00 & $17: 00$ & 19:00 & 18:00 \\
\hline & & $\mathrm{t}_{\text {min }}$ & $7: 00$ & 8:00 & $9: 00$ & 9:00 & 9:00 & $9: 00$ \\
\hline \multirow{4}{*}{$\begin{array}{l}\text { Bentonite } 16 \\
\mathrm{Mg} \mathrm{ha}^{-1} \text { in top } \\
10 \mathrm{~cm} \text { soil } \\
\text { layer }\end{array}$} & \multirow{4}{*}{ 03-02-13 } & $\mathrm{T}_{\text {max }}$ & 23.5 & 23.0 & 22.7 & 22.3 & 22.2 & 22.2 \\
\hline & & $\mathrm{T}_{\text {min }}$ & 14.3 & 14.8 & 15.0 & 15.0 & 14.9 & 13.2 \\
\hline & & $\mathrm{t}_{\max }$ & $14: 00$ & $15: 00$ & $16: 00$ & $17: 00$ & $18: 00$ & $17: 00$ \\
\hline & & $\mathrm{t}_{\text {min }}$ & 7:00 & 8:00 & 9:00 & 10:00 & 11:00 & 9:00 \\
\hline \multirow{4}{*}{$\begin{array}{c}\text { Bentonite } 16 \\
\mathrm{Mg} \mathrm{ha}^{-1} \text { in top } \\
20 \mathrm{~cm} \text { soil } \\
\text { layer }\end{array}$} & \multirow{4}{*}{$03-02-13$} & $\mathrm{~T}_{\text {max }}$ & 25.7 & 25.6 & 25.2 & 24.8 & 24.6 & 22.2 \\
\hline & & $\mathrm{T}_{\text {min }}$ & 11.2 & 11.8 & 12.1 & 12.4 & 12.3 & 13.2 \\
\hline & & $\mathrm{t}_{\max }$ & $15: 00$ & $16: 00$ & 17:00 & $18: 00$ & 19:00 & $17: 00$ \\
\hline & & $\mathrm{t}_{\text {min }}$ & $7: 00$ & 8:00 & 9:00 & 10:00 & 11:00 & 9:00 \\
\hline \multirow{4}{*}{ Control } & \multirow{4}{*}{$03-02-13$} & $\mathrm{~T}_{\max }$ & 27.9 & 27.5 & 26.0 & 25.7 & 25.5 & 22.2 \\
\hline & & $\mathrm{T}_{\text {min }}$ & 15.4 & 17.3 & 16.2 & 16.2 & 16.0 & 13.2 \\
\hline & & $\mathrm{t}_{\max }$ & $17: 00$ & 18:00 & 19:00 & $20: 00$ & $21: 00$ & $17: 00$ \\
\hline & & $\mathrm{t}_{\min }$ & 9:00 & 9:00 & 11:00 & 11:00 & $10: 00$ & $9: 00$ \\
\hline
\end{tabular}


MINIMIZING TEMPERATURE FLUCTUATIONS OF SANDY SOIL ... 201

TABLE 10. Maximum and minimum air and soil temperatures with their corresponding times for different soil depths at $30 \%$ depletion from soil field capacity during winter 2013

\begin{tabular}{|c|c|c|c|c|c|c|c|c|}
\hline \multirow[b]{2}{*}{ Treatment } & \multirow[b]{2}{*}{ Date } & \multirow{2}{*}{ Parameter } & \multicolumn{5}{|c|}{ Soil Depth } & \multirow{2}{*}{ Air } \\
\hline & & & $1 \mathrm{~cm}$ & $6 \mathrm{~cm}$ & $15 \mathrm{~cm}$ & $25 \mathrm{~cm}$ & $35 \mathrm{~cm}$ & \\
\hline \multirow{4}{*}{$\begin{array}{c}\text { Transparent } \\
\text { Plastic } \\
\text { Mulch }\end{array}$} & \multirow{4}{*}{$27-02-13$} & $\mathrm{~T}_{\max }$ & 38.2 & 36.9 & 32.4 & 32.2 & 32.0 & 26.4 \\
\hline & & $\mathrm{T}_{\text {min }}$ & 18.6 & 19.4 & 19.2 & 19.4 & 19.5 & 19.2 \\
\hline & & $\mathrm{t}_{\max }$ & $14: 00$ & $15: 00$ & $16: 00$ & $17: 00$ & 18:00 & $16: 00$ \\
\hline & & $\mathrm{t}_{\text {min }}$ & 8:00 & 9:00 & 9:00 & 10:00 & 11:00 & $10: 00$ \\
\hline \multirow{4}{*}{$\begin{array}{c}\text { Rice Straw } \\
\text { Mulch } 4 \mathrm{Mg} \\
\text { ha }^{-1}\end{array}$} & \multirow{4}{*}{$15-02-13$} & $\mathrm{~T}_{\max }$ & 24.6 & 24.0 & 23.8 & 23.4 & 23.2 & 21.4 \\
\hline & & $\mathrm{T}_{\text {min }}$ & 16.2 & 16.7 & 17.5 & 17.5 & 17.5 & 17.1 \\
\hline & & $\mathrm{t}_{\max }$ & $15: 00$ & $16: 00$ & $17: 00$ & $18: 00$ & 19:00 & 18:00 \\
\hline & & $\mathrm{t}_{\min }$ & 8:00 & 8:00 & 9:00 & $10: 00$ & 11:00 & 9:00 \\
\hline \multirow{4}{*}{$\begin{array}{c}\text { Rice Straw } \\
\text { Mulch } 8 \mathrm{Mg} \\
\mathrm{ha}^{-1}\end{array}$} & \multirow{4}{*}{$19-02-13$} & $\mathrm{~T}_{\max }$ & 28.2 & 27.2 & 25.7 & 25.2 & 24.5 & 22.2 \\
\hline & & $\mathrm{T}_{\min }$ & 14.3 & 15.5 & 15.3 & 16.8 & 16.3 & 14.2 \\
\hline & & $\mathrm{t}_{\max }$ & $14: 00$ & $15: 00$ & $16: 00$ & $17: 00$ & 18:00 & $18: 00$ \\
\hline & & $\mathrm{t}_{\text {min }}$ & 7:00 & 8:00 & 9:00 & 9:00 & 10:00 & 8:00 \\
\hline \multirow{4}{*}{$\begin{array}{l}\text { Bentonite } 16 \\
\mathrm{Mg} \mathrm{ha}^{-1} \text { in } \\
\text { top } 10 \mathrm{~cm} \\
\text { soil layer }\end{array}$} & \multirow{4}{*}{$08-02-13$} & $\mathrm{~T}_{\max }$ & 25.0 & 24.7 & 24.3 & 24.0 & 23.8 & 24.5 \\
\hline & & $\mathrm{T}_{\min }$ & 16.3 & 16.2 & 16.2 & 16.3 & 16.2 & 15.7 \\
\hline & & $\mathrm{t}_{\max }$ & $14: 00$ & $15: 00$ & $16: 00$ & $18: 00$ & 19:00 & $18: 00$ \\
\hline & & $\mathrm{t}_{\min }$ & 7:00 & 7:00 & 9:00 & 11:00 & $12: 00$ & 9:00 \\
\hline \multirow{4}{*}{$\begin{array}{l}\text { Bentonite } 16 \\
\mathrm{Mg} \mathrm{ha}^{-1} \text { in } \\
\text { top } 20 \mathrm{~cm} \\
\text { soil layer }\end{array}$} & \multirow{4}{*}{$08-02-13$} & $\mathrm{~T}_{\text {max }}$ & 27.7 & 27.3 & 27.0 & 26.7 & 26.5 & 24.5 \\
\hline & & $\mathrm{T}_{\text {min }}$ & 14.7 & 15.5 & 15.6 & 16.5 & 16.4 & 15.7 \\
\hline & & $\mathrm{t}_{\max }$ & $15: 00$ & $15: 00$ & $16: 00$ & $17: 00$ & 18:00 & $18: 00$ \\
\hline & & $\mathrm{t}_{\min }$ & 8:00 & 8:00 & 9:00 & 10:00 & 11:00 & 9:00 \\
\hline \multirow{4}{*}{ Control } & \multirow{4}{*}{$08-02-13$} & $\mathrm{~T}_{\text {max }}$ & 30.0 & 29.4 & 27.9 & 27.4 & 27.0 & 24.5 \\
\hline & & $\mathrm{T}_{\text {min }}$ & 17.3 & 19.1 & 17.8 & 18.3 & 18.1 & 15.7 \\
\hline & & $\mathrm{t}_{\max }$ & $17: 00$ & $18: 00$ & $18: 00$ & $19: 00$ & 20:00 & $18: 00$ \\
\hline & & $\mathrm{t}_{\text {min }}$ & $8: 00$ & 9:00 & 9:00 & 11:00 & $12: 00$ & 9:00 \\
\hline
\end{tabular}


TABLE 11. Maximum and minimum air and soil temperatures with their corresponding times for different soil depths at $45 \%$ depletion from soil field capacity during winter 2013

\begin{tabular}{|c|c|c|c|c|c|c|c|c|}
\hline \multirow[b]{2}{*}{ Treatment } & \multirow[b]{2}{*}{ Date } & \multirow{2}{*}{$\begin{array}{c}\text { Paramet } \\
\text { er }\end{array}$} & \multicolumn{5}{|c|}{ Soil Depth } & \multirow{2}{*}{ Air } \\
\hline & & & $1 \mathrm{~cm}$ & $6 \mathrm{~cm}$ & $15 \mathrm{~cm}$ & $25 \mathrm{~cm}$ & $35 \mathrm{~cm}$ & \\
\hline \multirow{4}{*}{$\begin{array}{c}\text { Transparen } \\
\text { t Plastic } \\
\text { Mulch }\end{array}$} & \multirow{4}{*}{$\begin{array}{c}18-03- \\
13\end{array}$} & $\mathrm{~T}_{\max }$ & 37.0 & 36.8 & 35.5 & 33.7 & 33.5 & 25.0 \\
\hline & & $\mathrm{T}_{\min }$ & 14.9 & 15.8 & 16.0 & 16.6 & 16.5 & 15.3 \\
\hline & & $\mathrm{t}_{\max }$ & $14: 00$ & $17: 00$ & $18: 00$ & $19: 00$ & $20: 00$ & $16: 00$ \\
\hline & & $\mathrm{t}_{\text {min }}$ & 7:00 & 7:00 & 7:00 & 9:00 & 9:00 & 8:00 \\
\hline \multirow{4}{*}{$\begin{array}{c}\text { Rice Straw } \\
\text { Mulch } 4 \\
\mathrm{Mg} \mathrm{ha}^{-1}\end{array}$} & \multirow{4}{*}{$\begin{array}{c}27-02- \\
13\end{array}$} & $\mathrm{~T}_{\max }$ & 26.3 & 26.0 & 25.8 & 25.7 & 25.6 & 26.4 \\
\hline & & $\mathrm{T}_{\min }$ & 16.2 & 16.8 & 17.1 & 17.3 & 17.3 & 19.2 \\
\hline & & $\mathrm{t}_{\max }$ & $15: 00$ & $16: 00$ & $17: 00$ & $18: 00$ & $19: 00$ & $16: 00$ \\
\hline & & $\mathrm{t}_{\text {min }}$ & 8:00 & 9:00 & $10: 00$ & 11:00 & $12: 00$ & 10:00 \\
\hline \multirow{4}{*}{$\begin{array}{c}\text { Rice Straw } \\
\text { Mulch } 8 \\
\text { Mg ha }^{-1}\end{array}$} & \multirow{4}{*}{$\begin{array}{c}13-03- \\
13\end{array}$} & $\mathrm{~T}_{\max }$ & 37.2 & 37.0 & 36.9 & 36.5 & 36.4 & 32.2 \\
\hline & & $\mathrm{T}_{\min }$ & 20.7 & 20.8 & 21.2 & 21.4 & 22.7 & 22.7 \\
\hline & & $\mathrm{t}_{\max }$ & $15: 00$ & $16: 00$ & $17: 00$ & $18: 00$ & $19: 00$ & $17: 00$ \\
\hline & & $\mathrm{t}_{\text {min }}$ & 8:00 & 9:00 & $10: 00$ & 11:00 & 10:00 & 9:00 \\
\hline \multirow{4}{*}{$\begin{array}{c}\text { Bentonite } \\
16 \mathrm{Mg} \mathrm{ha}^{-1} \\
\text { in top } 10 \\
\mathrm{~cm} \text { soil } \\
\text { layer }\end{array}$} & \multirow{4}{*}{$\begin{array}{c}19-02- \\
13\end{array}$} & $\mathrm{~T}_{\max }$ & 23.8 & 23.3 & 23.0 & 22.5 & 22.4 & 22.2 \\
\hline & & $\mathrm{T}_{\min }$ & 15.4 & 15.6 & 15.7 & 16.0 & 15.9 & 14.2 \\
\hline & & $\mathrm{t}_{\max }$ & $15: 00$ & $16: 00$ & $16: 00$ & $17: 00$ & $18: 00$ & $18: 00$ \\
\hline & & $\mathrm{t}_{\text {min }}$ & 8:00 & 8:00 & 9:00 & $10: 00$ & 11:00 & 8:00 \\
\hline \multirow{4}{*}{$\begin{array}{c}\text { Bentonite } \\
16 \mathrm{Mg} \mathrm{ha}^{-1} \\
\text { in top } 20 \\
\mathrm{~cm} \text { soil } \\
\text { layer }\end{array}$} & \multirow{4}{*}{$\begin{array}{c}19-02- \\
13\end{array}$} & $\mathrm{~T}_{\max }$ & 25.3 & 25.0 & 24.0 & 23.7 & 23.2 & 22.2 \\
\hline & & $\mathrm{T}_{\min }$ & 13.0 & 14.9 & 15.0 & 15.5 & 15.0 & 14.2 \\
\hline & & $\mathrm{t}_{\max }$ & $14: 00$ & $15: 00$ & $16: 00$ & $17: 00$ & $18: 00$ & 18:00 \\
\hline & & $\mathrm{t}_{\text {min }}$ & 7:00 & 8:00 & 9:00 & $10: 00$ & 11:00 & 8:00 \\
\hline \multirow{4}{*}{ Control } & \multirow{4}{*}{$\begin{array}{c}19-02- \\
13\end{array}$} & $\mathrm{~T}_{\max }$ & 26.3 & 26.2 & 25.0 & 24.9 & 24.6 & 22.2 \\
\hline & & $\mathrm{T}_{\min }$ & 16.9 & 18.5 & 17.6 & 17.6 & 17.7 & 14.2 \\
\hline & & $\mathrm{t}_{\text {max }}$ & $17: 00$ & 18:00 & $19: 00$ & $20: 00$ & $21: 00$ & $18: 00$ \\
\hline & & $\mathrm{t}_{\text {min }}$ & 7:00 & 8:00 & 9:00 & $10: 00$ & 11:00 & 8:00 \\
\hline
\end{tabular}

January, 26, 2013 was a promising day to evaluate the effects of the investigated treatments under the same soil moisture level and exact climatic conditions. On that day, soil moisture was at a whole field capacity. The maximum air temperature was $28.4{ }^{\circ} \mathrm{C}$ and the minimum was $12.0^{\circ} \mathrm{C}$, so the fluctuation in air temperature was $16.4{ }^{\circ} \mathrm{C}$. Because the maximum fluctuation of soil temperature was done in the uppermost soil layer, it was more appropriate to determine the effects of the treatments on the temperature fluctuation of such soil layer. The temperature fluctuations obtained for the uppermost soil layer were 12.6, 9.4, 7.0, 10.7, 9.7, and $11.1{ }^{\circ} \mathrm{C}$ for $\mathrm{TP}, \mathrm{R}_{4}, \mathrm{R}_{8}, \mathrm{~B}_{10}, \mathrm{~B}_{20}$, and $\mathrm{C}$ treatments, respectively. The highest soil temperature fluctuation was obtained under TP

Egypt. J. Soil Sci. 56, No. 2 (2016) 
treatment, with maximum value of $27.8^{\circ} \mathrm{C}$ and minimum value of $15.2{ }^{\circ} \mathrm{C}$. It also gave the highest maximum soil temperature. The difference between maximum soil temperatures obtained for TP and $\mathrm{C}$ was $2.4{ }^{\circ} \mathrm{C}$. A value of $3.0^{\circ} \mathrm{C}$ improved in soil temperature of the upper layer under transparent plastic mulch was reported by Yang et al. (2012). Our findings came in agreement with that reported by Li et al. (2011). They found that, soil temperature under transparent plastic showed a strong diurnal cycle with the highest temperature at 14:00 to 16:00 PM and lowest at 7:00 AM. Moreover, they reported that, the diurnal variation in soil temperature was $2-6{ }^{\circ} \mathrm{C}$ higher under plastic mulch compared to bare soil.

Rice straw resulted in a high maximum soil temperature and slightly low minimum values compared to $\mathrm{C}$ treatment. During the cold season, Zhang et al. (2009) observed that, soil temperatures under straw mulch were higher than that observed for the bare soil. During the colder periods, the input of solar radiation energy is lower and there is a net loss of soil heat energy to the atmosphere, resulting in a temperature decrease in soil profile.

Incorporating bentonite with soil resulted in decreasing soil temperature fluctuation from 11.1 for $\mathrm{C}$ treatment to 10.7 and $9.7{ }^{\circ} \mathrm{C}$ for $\mathrm{B}_{10}$ and $\mathrm{B}_{20}$ treatments, respectively. Mixing the bentonite with the upper $20 \mathrm{~cm}$ soil layer gave a lower soil temperature fluctuation compared to $\mathrm{C}$ and $\mathrm{B} 10$ treatments. This may be attributed to the effect of bentonite on soil moisture distribution at a more thickness soil layer.

The arrangement of treatments in descending order for the uppermost soil temperature fluctuation was TP, C, $\mathrm{B}_{10}, \mathrm{~B}_{20}, \mathrm{R}_{4}$, and $\mathrm{R}_{8}$ as indicated from Table 8 . So, it can be concluded that rice straw mulch was the most efficient treatment in moderating soil temperature fluctuations during the winter conditions of Ismailia, where soil moisture content was kept at soil field capacity. Similar conclusion was also stated during the summer period. So it can be recommended that, rice straw mulch is the most suitable practice for moderating soil temperature fluctuations during both summer and winter seasons. Almost similar trends were found for all investigated treatments at other soil moisture levels.

To elucidate the effects of the investigated treatments on soil temperature, the time rate of weighted average soil temperature changes $(\Delta T / \Delta t)$ were calculated for January, 26, 2013, where all treatments were at whole field capacity and subjected to the exact climatic conditions. The values obtained for the time rate of weighted average soil temperature rising during the heating period were 0.9500 , $0.7111,0.5000,0.8375,0.9714$ and $0.9571{ }^{\circ} \mathrm{C} \mathrm{h}^{-1}$ for $\mathrm{TP}, \mathrm{R}_{4}, \mathrm{R}_{8}, \mathrm{~B}_{10}, \mathrm{~B}_{20}$, and $\mathrm{C}$ treatments, respectively. The maximum time rate of temperature rising was recorded under B20 treatment. Similar result was found by Zvomuya et al. (2008) after bentonite application as drilling mud to sandy loam soil. They reported that bentonite application resulting in up to $18 \%$ decrease in soil albedo, which is an important parameter affecting the soil surface energy balance. The obtained values of both TP and B20 treatment were approximately the same. On the other

Egypt. J. Soil Sci. 56, No. 2 (2016) 
hand, the lowest time rate of weighted average temperature rising was obtained under R8 treatment. Most likely because it has a higher albedo and lower thermal conductivity compared to other treatments.

The time rate of the weighted average soil temperature falling during two cooling periods, from 0:00 Am to the time of minimum temperature and from time of maximum temperature to 0:00 AM next day. For all the investigated treatments, the obtained values were $-0.5187,-0.4600,-0.3133,-0.5750,-0.5529$ and $-0.4912{ }^{\circ} \mathrm{C} \mathrm{h}^{-1}$ for TP, R4, R8, B10, B20, and C, respectively. The highest value was obtained for B20 treatment, while the lowest value was obtained for R8 treatment. The presence of straw mulch on the soil surface insulates the soil from colder temperature, to some degree. Therefore, heat losses from the soil are somewhat lower under straw mulching than bare soil and soil temperature which are consequently higher (Horton et al. 1996).

\section{Soil moisture evaporation}

Figure 2 represents the changes in evaporation rate, in $g$ water per soil column per day, as a function of time. Nearly all investigated treatments have the same manner of initial high values of evaporation rate that rapidly decreased, then still stable at a low rate level. These two stages of evaporation could be named falling rate stage and slow rate stage as described by Hillel (2004). The treatments $B_{10}$, $\mathrm{B}_{20}$, and $\mathrm{C}$ almost have the same evaporation rate, and recorded the highest values of evaporation rate, then followed by $\mathrm{R}_{4}$ then $\mathrm{R}_{8}$ then TP. The TP treatment recorded the lowest evaporation rate, as the plastic sheets prevents most of the evaporated water vapor from escaping to the atmosphere. The water vapor was condensed on the inner surface of the plastic sheets and returned again to the soil surface.

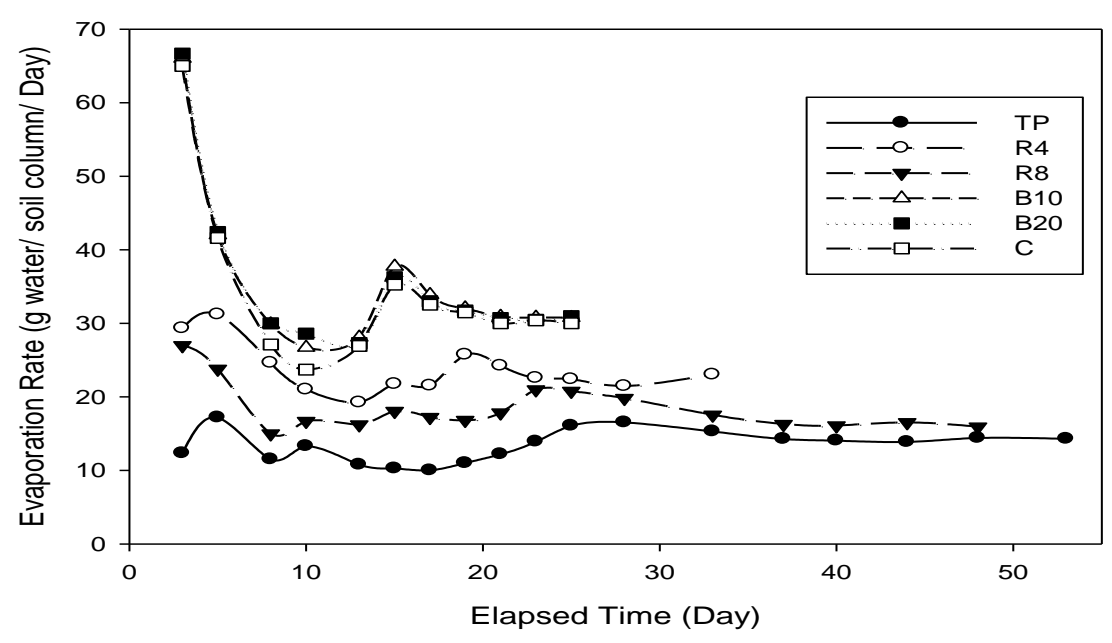

Fig. 2. Effect of different soil surface treatments on evaporation rate for Ismailia sandy soil during winter 2013

Egypt. J. Soil Sci. 56, No. 2 (2016) 
Soil moisture distribution along soil columns was presented for the six treatments at the three soil moisture depletion levels of 15, 30, and $45 \%$ from field capacity (Table 12). The investigated treatments exhibited very similar soil moisture distribution patterns. However, the lower soil section of soil columns at $15 \%$ depletion level represents soil moisture content more than its initial value. The reason for this finding may attributed to the rainfall occurred at the beginning of the experiment. At higher depletion levels such high values did not recorded, probably because the prolonged time period that cause soil water to redistribute. At 30\% depletion level both R4 and R8 recorded higher values of soil moisture contents at the soil surface, while all treatments recorded low values at $45 \%$ depletion level. For both 30 and $45 \%$ depletion levels, TP treatment recorded higher soil moisture content in the middle and lower sections of the soil column.

TABLE 12. Effect of bentonite incorporation and surface mulching on soil moisture distribution at different depletion levels for Ismailia sandy soil during winter 2013

\begin{tabular}{|c|c|c|c|c|c|c|}
\hline Treatment & $\mathbf{T P}$ & $\mathbf{R 4}$ & $\mathbf{R 8}$ & B10 & B20 & $\mathbf{C}$ \\
\hline $\begin{array}{r}\text { Depth } \\
(\mathrm{cm})\end{array}$ & \multicolumn{6}{|c|}{ At $15 \%$ Depletion from Soil Field Capacity } \\
\hline 1 & 0.0751 & 0.0877 & 0.0739 & 0.0624 & 0.0694 & 0.0722 \\
\hline 6 & 0.1013 & 0.1149 & 0.1129 & 0.1127 & 0.1076 & 0.1018 \\
\hline 15 & 0.1217 & 0.1213 & 0.1164 & 0.1228 & 0.1229 & 0.1045 \\
\hline 25 & 0.1266 & 0.1227 & 0.1183 & 0.1328 & 0.1394 & 0.1538 \\
\hline 35 & 0.1587 & 0.1515 & 0.1579 & 0.1535 & 0.1399 & 0.1555 \\
\hline & \multicolumn{6}{|c|}{ At $30 \%$ Depletion from Soil Field Capacity } \\
\hline 1 & 0.0241 & 0.0592 & 0.0529 & 0.0266 & 0.0130 & 0.0138 \\
\hline 6 & 0.0765 & 0.0854 & 0.0804 & 0.0832 & 0.0893 & 0.0853 \\
\hline 15 & 0.0861 & 0.0856 & 0.1003 & 0.1000 & 0.1057 & 0.0935 \\
\hline 25 & 0.1131 & 0.1063 & 0.1096 & 0.1088 & 0.1074 & 0.1108 \\
\hline 35 & 0.1499 & 0.1416 & 0.1250 & 0.1257 & 0.1239 & 0.1313 \\
\hline & \multicolumn{6}{|c|}{ At $45 \%$ Depletion from Soil Field Capacity } \\
\hline 1 & 0.0041 & 0.0054 & 0.0070 & 0.0132 & 0.0042 & 0.0028 \\
\hline 6 & 0.0514 & 0.0561 & 0.0517 & 0.0812 & 0.0659 & 0.0415 \\
\hline 15 & 0.0609 & 0.0840 & 0.0750 & 0.0842 & 0.0850 & 0.0868 \\
\hline 25 & 0.0930 & 0.0915 & 0.0949 & 0.0882 & 0.0902 & 0.0962 \\
\hline 35 & 0.1301 & 0.1037 & 0.1107 & 0.0947 & 0.1014 & 0.1119 \\
\hline
\end{tabular}

\section{Conclusion}

The previous discussion signposted that, during both summer and winter conditions rice straw mulch was a favorable treatment to moderate fluctuation in soil temperature, and reducing maximum value of soil temperature as well. Such practice may well be used for enhancement of plant growth. Contrary, transparent plastic mulch resulted in much fluctuation in soil temperature, with high maximum values. This effect may be harmful for some plant species, especially during summer. Bentonite incorporation also had an effect on moderating soil temperature fluctuation, which was better than untreated soil, i.e., control. 


\section{References}

Anikwe, M.A.N., Mbah, C.N., Ezeaku, P.I. and Onyia, V.N. (2007) Tillage and plastic mulch effects on soil properties and growth and yield of cocoyam (Colocasia esculenta) on an ultisol in southeastern Nigeria. Soil \& Tillage Research, 93, 264-272.

Bellini, G., Sumner, M. E., Radcliffe, D. E. and Qafoku, N. P. (1996) Anion transport through columns of highly weathered acid soil: Adsorption and retardation. Soil Sci. Soc. Am. J. 60, 132-137.

Dahiya, R., Ingwersen, J. and Streck, T. (2007) The effect of mulching and tillage on the water and temperature regimes of a loess soil: Experimental findings and modeling. Soil Till. Res. 96, 52-63.

Emmert, E.M. (1957) Black polyethylene for mulching vegetables. Proc. Amer. Soc. Hort. Sci. 69, 464-469.

Fabrizzi, K.P., Garcia, F.O., Costa, J.L. and Picone, L.I., (2005) Soil water dynamics, physical properties and corn and wheat responses to minimum and no-tillage systems in the southern Pampas of Argentina. Soil Till. Res. 81 (1), 57-69.

Geiger, R. (1959) The Climate Near the Ground. $3^{\text {rd }}$ ed. Harvard University Press, Cambridge, Massachusetts. U.S.A.

Gregory, P. J. (2006) Plant Roots: Growth, Activity and Interaction with Soils. Blackwell Publishing Ltd, Oxford, UK. pp 132.

Hillel, D. (2004) Introduction to Environmental Soil Physics. Academic Press, El-Sevier Science USA.

Horton, R., Bristow, K.L., Kluitenberg, G.J. and Sauer, T.J. (1996) Crop residue effects on surface radiation and energy balance-review. Theor. Appl. Climatol. 54, $27-37$.

Kirnak, H., Kaya, C., Higgs, D. and Tas, I. (2003) Response of drip irrigated bell pepper to water stress and different nitrogen levels with or without mulch cover. Journal of Plant Nutrition. 26(2), 263-277.

Klute, A. (1986) (Ed.) Methods of Soil Analysis. Part 1: Physical and Mineralogical Methods, SSSA INCS., Madison, Wisconsin USA.

Lal, R. and Shukla, M. K. (2004) Principles of Soil Physics. Marcel Dekker, Inc. New York. Basel.

Li, Z. G., Zhang, R. H., Wang, X. J., Wang, J. P., Zhang, C. P. and Tian, C. Y. (2011) Carbon dioxide fluxes and concentrations in a cotton field in northwestern China: Effects of plastic mulching and drip irrigation. Pedosphere, 21(2), 178-185.

Liu, M. X., Yang, J. S., Li, X. M., Yu, M. and Wang, J. (2013) Numerical simulation of soil water dynamics in a drip irrigated cotton field under plastic mulch. Pedosphere, 23(5), 620-635.

Egypt. J. Soil Sci. 56, No. 2 (2016) 
Mount, H. R. and Paetzold, R. F. (2002) The temperature regime for selected soils in the United States. Soil Survey Investigation Report No. 48. USDA-NRCS. Lincoln, NE.

Munguia, J., Zermeńo, A., Quezada, R. and Hipps, L.E. (1999) Effects of black plastic mulch on the energy balance components of muskmelon crop. Proc. Natl. Agr. Plast. Congr. 28, 134-138.

Olasantan, F.O. (1999) Effect of time of mulching on soil temperature and moisture regime and emergence, growth and yield of white yam in western Nigeria. Soil Till. Res. 50 (3-4), 215-221.

Sarkar, S., Paramanick, M. and Goswami, S.B. (2007) Soil temperature, water use and yield of yellow sarson (Brassica napus L. var. glauca) in relation to tillage intensity and mulch management under rainfed lowland ecosystem in eastern India. Soil Till. Res. 93, 94-101.

Sheta, A. S., Al-Omran, A. M. and Falatah, A. M. (2006) Effect of clay deposits on physicochemical and intermittent evaporation characteristics of torripsamment. Arid Land Research and Management, 20, 295-307.

Shinde, D. (1997) Modeling Coupled Water-Heat Flow and Impacts upon Chemical Transport in Mulched Soil Beds. A Ph.D. dissertation presented to the graduate school, University of Florida, 1997.

Soil Survey Staff (1993) Soil Survey Manual. U.S.D.A. Agriculture Handbook No. 18 U.S. Government Printing Office, Washington, D.C.

Soil Survey Staff (2006) Keys to Soil Taxonomy. 10th ed. NRCS, Washington, DC.

Sparks, D.L. (1996) (Ed.) Methods of Soil Analysis. Part 3 Chemical Methods, SSSA INCS., Madison, Wisconsin USA.

Spiegel, M. and Stephen, L. (1998) Theory and Problems of Statistics. $3^{\text {rd }}$ ed., Schaum's outline series. McGraw-Hill, New York.

Tejedor, M., Jiménez, C. Rodríguez, M. and Neris, J. (2009) Controversies in the Definition of "Iso" Soil Temperature Regimes. Soil Sci. Soc. Am. J. 73, 983-988.

Wu, C.L., Chau, K.W. and Huang, J.S. (2007) Modelling coupled water and heat transport in a soil-mulch-plant-atmosphere continuum (SMPAC) system. Applied Mathematical Modelling, 31, 152-169.

Yaghi, T., Arslana, A. and Naoumb, F. (2013) Cucumber (Cucumis sativus, L.) water use efficiency (WUE) under plastic mulch and drip irrigation. Agricultural Water Management, 128, 149- 157.

Yang, Q., Zuo, H., Xiao, X., Wang, S., Chen, B. and Chen, J. (2012) Modelling the effects of plastic mulch on water, heat and $\mathrm{CO}_{2}$ fluxes over cropland in an arid region. Journal of Hydrology, 452-453 (2012) 102-118. 
Zhang, S., Lövdahl, L., Grip, H., Tong, Y., Yang, X. and Wanga, Q. (2009) Effects of mulching and catch cropping on soil temperature, soil moisture and wheat yield on the Loess Plateau of China. Soil Till. Res. 102, 78-86.

Zhao, H., Xiong, Y., Li, F., Wang, R., Qiang, S., Yao, T. and Mo, F. (2012) Plastic film mulch for half growing-season maximized WUE and yield of potato via moisturetemperature improvement in a semi-arid agroecosystem. Agricultural Water Management, 104, 68-78

Zvomuya, F., Larney, F. J., McGinn, S. M., Olson, A. F. and Willms, W. D.(2008) Surface albedo and soil heat flux changes following drilling mud application to a semiarid, mixed-grass prairie. Soil Sci. Soc. Am. J. 72, 1217-1225.

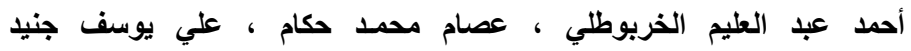

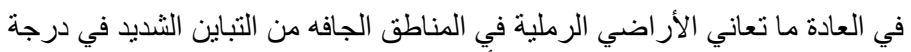

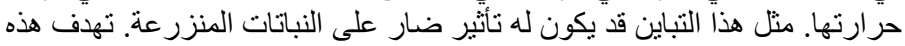

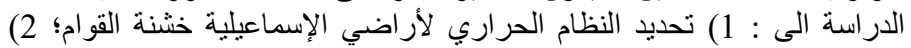

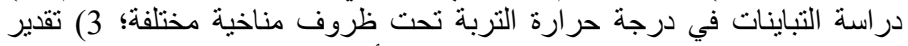

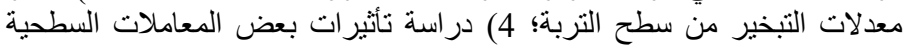

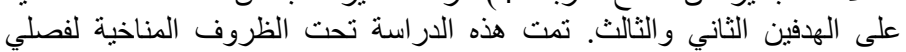

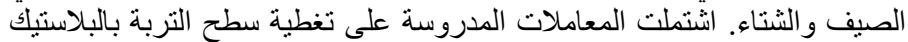

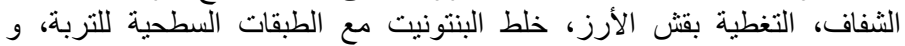

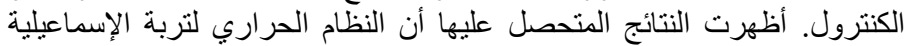
خشنة القوام هو الظهرت

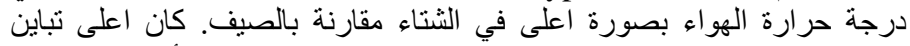

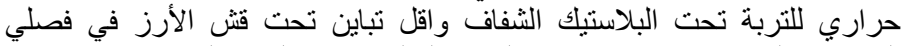

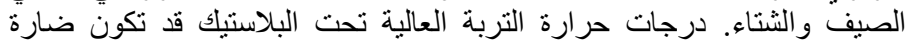

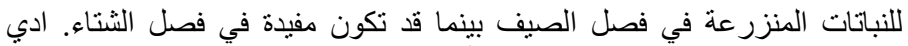

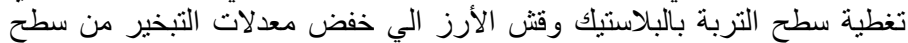

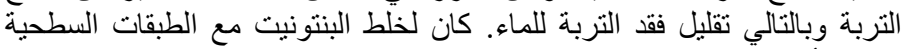

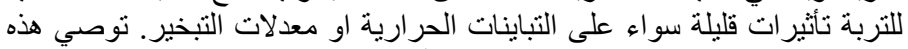

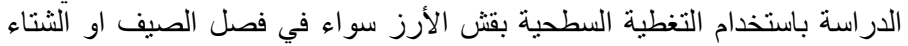

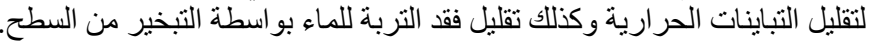


